\title{
Green innovation and organizational performance: The influence of big data and the moderating role of management commitment and HR practices
}

\author{
Abdul-Nasser El-Kassar ${ }^{\mathrm{a}}$, Sanjay Kumar Singh ${ }^{\mathrm{b}, *}$ \\ a Adnan Kassar School of Business, Lebanese American University, Beirut, Lebanon \\ b College of Business, Abu Dhabi University, P.O. Box 59911, Abu Dhabi, United Arab Emirates
}

\section{A R T I C L E I N F O}

\section{Keywords:}

Green innovation

Corporate environmental ethics

Large scale data

Human resource practices

Management commitment

Environmental and economic performance

\begin{abstract}
A B S T R A C T
Faced with internal and external pressure to adapt and implement environmental friendly business activities, it is becoming crucial for firms to identify practices that enhance their competitive advantage, economic, and environmental performance. Green innovation, green technologies, and the implementation of green supply chain management are examples of such practices. Green innovation and the adoption of the combination of green product innovation and green process innovation involve reduction in consumption of energy and pollution emission, recycling of wastes, sustainable utilization of resources, and green product designs.

Although the extent research in this area is substantial, research on the importance of considering corporate environmental ethics, stakeholders view of green product, and demand for green products as drivers of green innovation must be conducted. Moreover, the role of large scale data, management commitment, and human resource practices play to overcome the technological challenges, achieve competitive advantage, and enhance the economic and environmental performance have yet to be addressed. This paper develops and tests a holistic model that depicts and examines the relationships among green innovation, its drivers, as well as factors that help overcome the technological challenges and influence the performance and competitive advantage of the firm. This paper is among the first works to deal with such a complex framework which considers the interrelationships among numerous constructs and their effects on competitive advantage as well as overall organizational performance. A questionnaire was designed to measure the influence of green innovation adoption/ implementation and its drivers on performance and competitive advantage while taking into consideration the impact of management commitment and HR practices, as well as the use of large data on these relationships. Data collected from a sample of 215 respondents working in Middle East and North Africa (MENA) region and Golf-Cooperation Countries (GCC) were used to test the proposed relationships. The proposed model proved to be fit. The hypotheses were supported, and implications were discussed.
\end{abstract}

\section{Introduction}

Environmental concerns and resource limitations have made environmental pollution and sustainable utilization of resources vital global issues. Extensive economic development over the years cannot go hand in hand with the sustainable management of resources and the reduction of pollution (Wang and Song, 2014). Creating balance between economic development and high resource consumption remains a permanent challenge that forces firms to practice environmentalfriendly business activities with high economic value (Chan et al., 2012). In fact, firms are pushed towards identifying such activities that create an economic value while being more eco-efficient as the social consideration of environmental-friendly business practices increases (Chen and Delmas, 2012).
Green innovation, green technologies, and the implementation of green supply chain management are models of practices that must be implemented in order to leverage the effect of these challenges. Green innovation is in fact an important strategic catalyst to obtain sustainable development, including technological innovation involved in energy-saving, pollution-prevention, and waste recycling (Chang, 2011). Moreover, green innovation may be divided into green product and green processes that are designed for reducing energy and pollution emission, recycling of wastes, and utilizing sustainable resources (Chen et al., 2006).

With the increase in the implementation of green innovations and technologies, the importance of addressing key drivers that support such activities is emphasized. Recent studies identify, among others, corporate environmental ethics, stakeholders' view of green product,

\footnotetext{
* Corresponding author.

E-mail addresses: abdulnasser.kassar@lau.edu.lb (A.-N. El-Kassar), sanjay.singh@adu.ac.ae (S.K. Singh).
} 
and market demand for green products as contributors to the success of the implementation (Chang, 2011; Lin et al., 2013; Weng et al., 2015; Zhu et al., 2013). However, technological challenges become greater as firms adopt green innovation and sustainable practices internally and in association with other firms in the supply chain. Such challenges are tackled with large scale data, top management commitment, and human resource (HR) practices that focus on achieving competitive advantage and improving environmental and firm performance (Ar, 2012; Gunasekaran et al., 2017; Rajesh, 2017).

Yen and Yen (2012) examined the internal motives influencing firms' adoption of green purchasing such as top management commitment and partnerships with suppliers as well as external motives that include regulatory and customer pressure. They found that there's a direct relation between successful adoption of green standards and top management commitment, making it a key driver for green purchase adoption. This is further explained as internal drivers surpass external ones. Gholami et al. (2013) discussed senior managers' insight about circumstances and consequences of green technology adoption. They showed that green technology adoption, management's attitude and concern for potential consequences are significantly interrelated. In addition, they found that there is a positive link between green adoption and overall environmental performance.

HR practices have been linked with green management, technology/operations management and found to have contributing roles in organizational sustainability and to boost the performance of the firm (Boudreau, 2003; Boudreau et al., 2003; Jabbour et al., 2017; Jabbour and de Sousa Jabbour, 2016).

With the extensive research in this area, there remains a need for further research on the impact of corporate environmental ethics, stakeholders' view of green product, and demand for green products as drivers of green innovation. Furthermore, it is crucial to address the role of large scale data, management commitment, and human resource practices to conquer technological challenges, achieve competitive advantage, and enhance economic and environmental performance.

This paper aims to develop a holistic model linking corporate environmental ethics, stakeholders' view of green product, and demand for green products as drivers of green innovation to achieve competitive advantage and sustainable performance. The model takes into consideration management commitment, HR practices and the use/implementation of large data as factors that help overcome the technological challenges. In particular, the paper addresses the following questions:

- To what extent corporate environmental ethics, stakeholders' view of green product, market demand for green products, and big data influence green innovation, performance, and competitive advantage?

- To what extent management commitment and HR practices influence the aforementioned relationships?

Data collected from a sample of 215 respondents working in the Middle East and North Africa (MENA) region and Golf-Cooperation Countries (GCC), mostly in Lebanon, Egypt, Saudi Arabia and UAE, were used to test the model and answer the research questions.

By examining the proposed model and testing the corresponding hypotheses, this study is one of the first works that considers such a complex framework examining relationships among numerous and various constructs. It links top management commitment, stakeholders' view, corporate environmental ethics, and market demand for green products as well as HR practices with Big Data Adoption, assimilation, and routinization, green innovation practices (products and processes), competitive advantage, and environmental and economic performance.

The remainder of the paper is organized as follows:

In Section 2, previous studies related to this research are reviewed. In addition, the theoretical framework underlying our proposed model is presented, and the hypotheses are derived in Section 2. The research methodology and data analysis results are presented and discussed in Section 3. Finally, the conclusion, limitations, implications, recommendations and suggestions for future research are given in Section 4.

\section{Literature review and theoretical framework}

This study draws upon the resource-based view (RBV) theory of the firm. RBV proposes that competitive advantage can be achieved by organizations upon the creation of strategic and/or capabilities that are valued, rare, inimitable, non-transferable, and non-substitutable (Barney, 1991; Barney et al., 2001; Sirmon et al., 2011). The degree to which a firm possesses and manages such resources signifies superior firm performance (Amit and Schoemaker, 1993; Barney et al., 2001). In addition to the physical resources, those strategic resources may refer to organizational capabilities (Ulrich and Lake, 1990), human capital (Lado and Wilson, 1994), as well as technological and reputational capital (Größler and Grübner, 2006). The most important property of a resource needed to achieve and maintain competitive advantage is inimitability driven by path dependency (learning and know-how growing overtime), causal ambiguity (difficult to analyze its parts or determine how to recreate it), and social complexity (trust, reputation, employee-organization identification ...) (Dess et al., 2005).

Organizational capabilities are a complete necessity (Hitt et al., 2011) and depend on the environmental conditions in which an organization operates. Faced with internal and external pressure to adapt and implement environmental friendly business activities, it is becoming increasingly important for firms to develop green organizational capabilities. Identifying environmental friendly business activities is becoming more crucial as firms are faced with internal and external pressure from environmental agencies, governmental associations, competitors, stakeholders, employees, and customers (Weng et al., 2015). This urges business organizations to adopt programs such as green products, green technologies, and implement green supply chain management practices (Chiou et al., 2011).

Rapid increase in pollution accompanied by a decline in natural resources has prompted both governments and the society to push for green innovation on a larger scale. Zailani et al. (2015) investigated the causal factors behind adopting green innovation and its impact on firm performance. They identified market demand, firm internal initiatives, and environmental regulations as drivers for green innovation initiatives.

Green programs are adopted only when firms believe that such practices would lead to financial gain, operational improvement, and enhancement of their competitive advantage (Chiou et al., 2011). The implementation of green programs would likely improve the overall environmental performance of the organization (Chithambaranathan et al., 2015; Weng et al., 2015).

The adoption of green product innovation and green process innovation is positively related to corporate competitive advantage and environmental performance (Chen et al., 2006). This relation is in turn influenced by green supply chain management (Chiou et al., 2011). Chithambaranathan et al. (2015) argue that the environmental performance will be further enhanced if such green practices are adopted by the partners in the supply chain. The entire supply chain will be green if suppliers adopt the requirements of firms and customers. In fact, such practices adopted by the supplier had been shown to enhance green product innovation which in turn leads to better environmental performance and competitive advantage (Chiou et al., 2011). Furthermore, there is a substantial positive relation between environmental supply chain practices and the firm's performance on the market, operational, and accounting level, which further reinforces the impact of sustainable supply chain management on increasing firm performance (Golicic and Smith, 2013).

Green innovation is a combination of both green product and green process innovation that involves reduction in consumption of energy 
and pollution emission, recycling of wastes, and green product designs (Chen et al., 2006). In addition to internal and external pressure, the corporate environmental culture and values had been shown to impact competitive advantage through green product and process innovation (Chang, 2011; Zhu et al., 2013).

One of the driving forces for green innovativeness and competitive advantage is corporate environmental ethics which is a main element of the overall organizational structure (Peng and Lin, 2008). Corporate ethics designates expected ethical behavior and values of the organization and enforces green innovation and competitive advantage (Chang, 2011). Barney (1986) showed that organizational culture enhances sustainable competitive advantage and development if such culture is valuable and unique. In addition, sustainable development is achieved when green management and green innovation is part of the overall firm's mission (Marcus and Fremeth, 2009).

Along with corporate ethics, stakeholder's view of green product is also considered a key driver for green innovation. In fact, green capabilities and practices of a company are influenced by the concerns of various stakeholders internally and externally such as customers, preferences of business owners, suppliers, and governmental regulations (Weng et al., 2015). Once the firm considers such important drivers in their businesses, this will facilitate the adoption of green innovation and green practices (Routroy, 2009). Sezen and Çankaya (2013) indicated that firms are reconsidering their production processes in response to external societal and governmental pressures oriented towards an environmental friendly wellbeing.

Another key factor that pushes the organization towards adopting green innovation practices is market demand for green product (Wei and Morgan, 2004). It is important for firms to understand the strategic and operational implications of market demand as part of enhancing firm performance (Lin et al., 2013). Chiou et al. (2011) found that over time customers are increasingly becoming green conscious and likely to demand more 'green' products. This drives the firm to adopt green product innovation and integrate environmental friendly processes to produce sustainable products, meet market demand, and gain competitive advantage (Reinhardt, 1998; Zhou et al., 2009). Based on the above discussion, the following hypotheses are proposed:

H1. Corporate environmental ethics, stakeholders view and market demand for green products positively influence green innovation practices.

H2. Green innovation practices positively influence competitive advantage, organizational and environmental performance.

Resources can be directed towards tangible and intangible assets and have remarkable value when integrated or bundled (Grant, 1991; Sirmon et al., 2008). Capabilities are non-transferable subsets of a firm's resources directed at improving productivity (Makadok, 1999). Big Data can be defined as large quantities or volumes of data sets that cannot managed by typical available data means in terms of acquisition, access, analytics, and application in a reasonable amount of time (Hampton et al., 2013; Tien, 2013). Large scale data warehouses presented the issue of rich data but poor information (Tien, 2013). Gunasekaran et al. (2017) presented a resource-based perspective about the influence Big Data. It can be defined as massive quantities or volumes of data sets still not managed by typical available data means in terms of acquisition, access, analytics, and application in a reasonable amount of time (Hampton et al., 2013; Tien, 2013). Large scale data warehouses presented the issue of rich data but poor information (Tien, 2013). The Big Data and Predictive Analytics (BDPA) assimilation on both the supply chain and organizational performance. The proposed model suggests that business value is achieved by big data moderated by top management commitment (Gunasekaran et al., 2017).

The use of large scale data is also a contributing factor to overcome technological challenges. It is related to the degree of utilization of technology in organizational operations and depicted as a three stage process: large scale data acceptance, routinization, and assimilation (Gunasekaran et al., 2017; Hazen et al., 2012; Saga and Zmud, 1994). First, big data acceptance is related to how well stakeholders understand the importance of such technologies under the mediation effect of top management commitment (Gunasekaran et al., 2017). Second, Big Data Routinization is linked to the governance system of an organization that assists in the integration of technology (Zmud and Apple, 1992). And third, Big Data Assimilation is concerned with the extent to which technology is incorporated or spread across the organization's processes in order to achieve anticipated benefits (Hazen et al., 2012).

Due to the rapid development of data collection capacities and storage technologies, data available become too large or unstructured to be managed and traditional analytics may no longer yield smarter more insightful analyses (Li et al., 2016). Big data entails much more than applying new analytics. In fact, companies that learn to take advantage of big data unleash new organizational capabilities and value (Braganza et al., 2017; Davenport et al., 2012; Rajesh, 2017). Tien (2013) indicated that big data offers knowledgeable information assisting the decision-making processes. To obtain such information, data quality issues and access restrictions should be tackled with on-demand cloud computing, causative analysis with correlative data analytics, and model-driven with evidence-driven applications. In addition, big data is further promoted and advanced via the implementation of new acquisition, access, analytics and application technologies (Tien, 2013).

Although academics have proposed many examples of big data initiatives, many top managers are still reluctant to regularly allocate resources to big data. Braganza et al. (2017) identified creating a business process model for big data initiatives and building a strong potential with big data initiatives as contributing factors that support organizational resource management in big data initiatives. Furthermore, recognizing pitfalls of RBV and its assumptions that relate to big data is another contributing factor that support organizational resource management in big data initiatives.

Big data relates to a large-volume and complex data sets from numerous, independent sources (Wu et al., 2014). Sources of big data include the clickstream data from the Web, social media content, and video data from retail stores. Cloud computing is an important technological tool utilized to deal with massive and complicated computing without the costly maintenance of hardware, software, or related space (Hashem et al., 2015). Sivarajah et al. (2017) indicated that big data analytics is a trend for developing credible sources of information from big data that support decision-making. In addition, they established that utilizing big data analytics can enhance the overall operational efficiency and strategic potentials, and establish new techniques to increase revenue and competitive advantages (Papadopoulos et al., 2017). It is important for organizations to grasp the big data landscape before buying and deploying costly tools. The influx of big data in large quantity, high velocity, and high diversity created a challenge for traditional environmental evaluation theories and methods despite being imperfect in accuracy and stability (Song et al., 2016). Big data has been shown to have environmental and social impacts on innovation and performance of the supply chain (Cajaiba-Santana, 2014; Dubey et al., 2017; Huang et al., 2017; Roßmann et al., 2017; Papadopoulos et al., 2017). Dubey et al. (2017) addressed the questions of how and when large scale data can enhance environmental sustainability in supply chains.

Understanding the big data outlook entails a comprehensive view of big data challenges and practices that firms employ, and has consequences that affect investment decisions. Hence, we propose the following hypotheses:

H3. Big data and predictive analytics positively influence green innovation practices, competitive advantage and organizational performance.

H4. Corporate environmental ethics, stakeholders view, market demand for green products, and big data positively influence 
competitive advantage, organizational and environmental performance.

RBV recognizes that resources cannot provide competitive advantage by themselves. A study by Sirmon et al. (2007) highlighted the role of top managers in capability building, and structuring the resource portfolio using the particular processes (acquiring, accumulating, and divesting). Other studies investigated the importance of managerial decisions in resource acquisition and deployment (Grewal and Slotegraaf, 2007), and the role of managers in orchestrating resources (Chadwick et al., 2015). However, few studies investigated the effect of the combination of resources and capabilities on performance (Brandon-Jones et al., 2014; Ravichandran and Lertwongsatien, 2005; Rungtusanatham et al., 2003). For instance, Wu et al. (2006) argue that the utilization of capabilities may help organizations achieve or sustain competitive advantage.

Although the proper drivers are necessary, previous studies suggest that higher firm performance and competitive advantage through green practices may not be attained without management commitment, proper HR practices, and use of large scale data (Gunasekaran et al., 2017). These factors are crucial to overcome the technological challenges of green innovation.

Top management commitment plays an essential role in allocating resources, building capabilities, and helping the firm gain competitive advantage (Chadwick et al., 2015; Sirmon et al., 2007). The knowledge and beliefs of top management influences the implementation of technologies such as large scale data throughout the organization (Chatterjee et al., 2002). Managerial environmental interest influence how green innovation practices impact firm performance and competitive capabilities (Ar, 2012).

Proper human resource management practices are considered another element that firms employ to face technological challenges of green innovation. Such practices refer to hiring and retaining employees with innovative capabilities and skills and managing these resources to achieve competitive advantages (Sirmon and Hitt, 2003). Moreover, higher firm performance is positively related to the deployment of employees' skills and talents through such HR practices (Chrisman et al., 2003).

Linking HR practices with green management and technology/operations management has been debated (Boudreau, 2003; Boudreau et al., 2003; Jabbour et al., 2017; Jabbour and de Sousa Jabbour, 2016). Boudreau et al. (2003) studied the interface between operations and human resources. In particular, they examined how human considerations affect classical operations management. Boudreau et al. (2003) proposed a framework that tangibly connects organizational decisions about talent with sustainability. The proposed framework makes sustainability more actionable, helps achieving optimal returns from HR investments, and boosts the overall financial performance of firms. They also discussed the influence of efficiency and effectiveness on sustainability. Jabbour and de Sousa Jabbour (2016) proposed a framework that integrates green human resource management and green supply chain management, two important areas in HR management and operations management with contributing roles in organizational sustainability. They found that green supply chain management enhance firm's performance and affect its ability to invest in HR development and corporate social responsibility leading to the sustainable development of firms and supply chains. Thus, the following hypothesis is posit:

H5. HR practices, training and management commitment moderate the relationships in $\mathrm{H} 1$ to $\mathrm{H} 4$.

The aforementioned discussion can be summarized in the conceptual model depicted in Fig. 1.

\section{Research methodology and data analysis}

\subsection{Survey and data collection}

This study employs correlational design to examine the relationships between green innovation practices, corporate environmental ethics, stakeholders view, market demand for green products, large scale data. It also explores the potential causal impact of each of these factors on organizational and environmental performance as well the competitive advantage of the firm. In addition, this study aims to examine the influence of management commitment and HR practices on these relationships.

To examine the conceptual model and test these relationships, a survey instrument was designed, and measurement scales were developed. The draft questionnaire was constructed and content validity of the scale was checked and improved with the help of six academics and three experts from the industry. A revised version questionnaire was finalized and then used to test the proposed hypotheses. The measurement scales in the used questionnaire consisted of items representing respondents' attitudes and opinions about the green innovation practices, the related factors as well as the competitive advantage, the organizational and environmental performance of their companies. All items measuring these variables and the scales are discussed below.

To conduct the study, the target population was identified. It consisted of employees and managers, both middle and senior level, working in organizations that had adopted green innovation practices. These employees and managers were knowledgeable about the adopted innovation, the related technological and managerial factors as well as the performance of the organization. A convenience sampling procedure was followed. Potential respondents were approached through personal contacts via email and were asked to participate. 400 questionnaires were distributed with a cover letter that ensured the anonymity of answers and that included a brief explanation of the research. Stressing assurance of anonymity in the cover letter of the questionnaire aimed at minimizing the social desirability bias arising in survey research on sustainable development, especially in small firms (Roxas and Lindsay, 2012). Out of the returned questionnaires, 215 were found usable, yielding a response rate of $53.8 \%$.

Non-response bias was checked by contacting 23 non-respondents and asked about the reasons for not participating in the study. Lack of knowledge of the various constructs and items in the questionnaire was identified as the main reason. In addition, the demographic values were used to conduct a Chi-Square test that allows for a comparison between those who responded early (within the first two weeks) and those who responded late (contacted several times and responded after 20 to 25 days). The test was not significant indicating that those who responded late (having some of the non-respondents' characteristics) did not significantly differ from those who responded early. This provides additional evidence of non-response bias.

\subsection{Measures}

All of the constructs were measured with multiple-scale items. In all, sixty-six question items, excluding items that asked about company demographics, were used and covered all variables discussed in the model.

The construct corporate environmental ethics (CEE) was measured with three items drawn from Chang (2011). These items measured the degree to which environmental ethics and concern are included in the company's policies, mission, and vision. Stakeholder View (SV) of green products was measured with five items based on Weng et al. (2015). These items measured the implementation of environmental strategies and the operations undertaken by both internal and external stakeholders such as customers, competitors, and the industrial sector. Market Demand (MD) for green products was measured with four items 


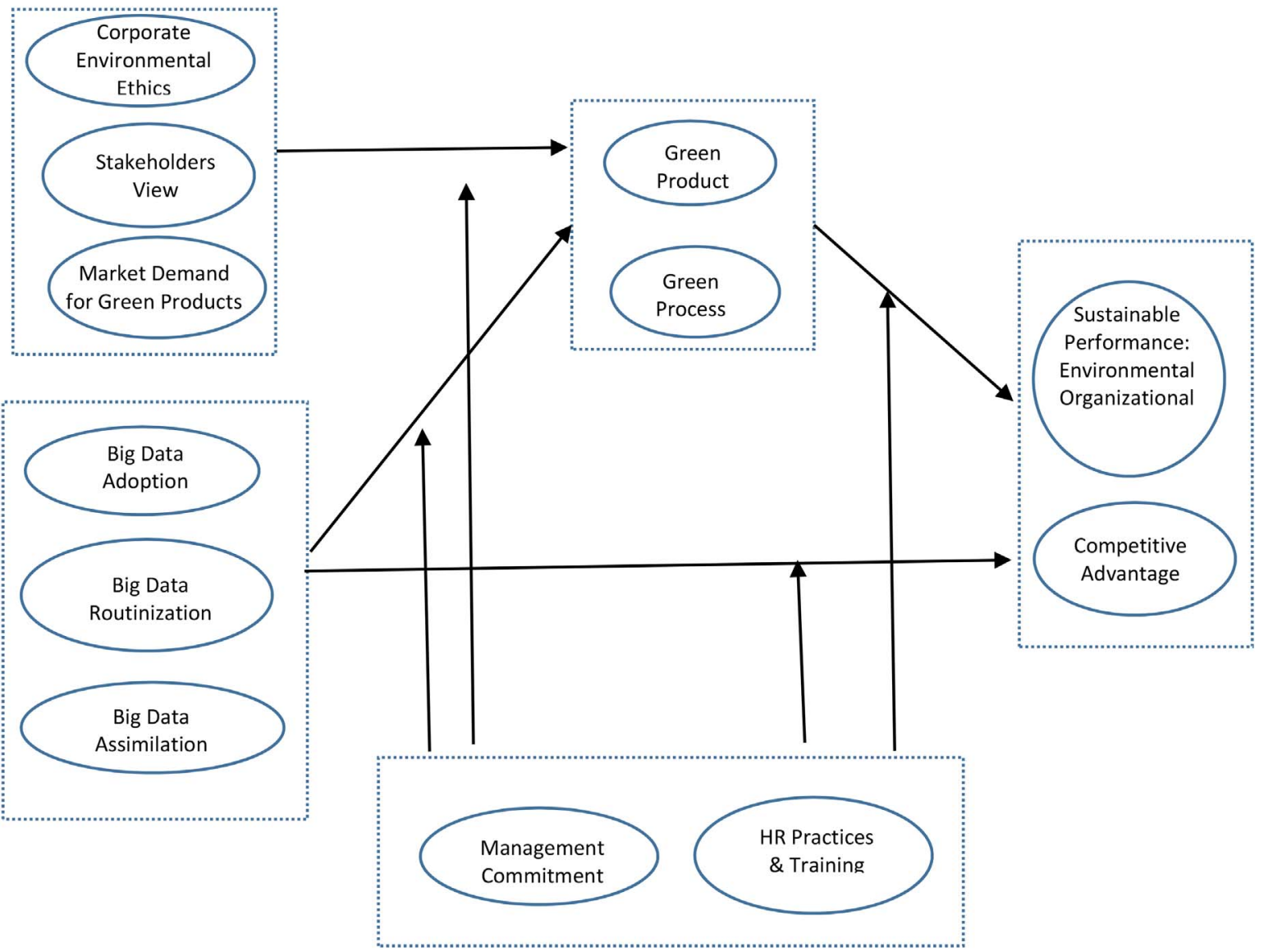

Fig. 1. The conceptual model.

Table 1

Drivers of green innovation.

\begin{tabular}{|c|c|c|c|c|}
\hline Construct & & Items & Factor loadings & Cronbach alpha \\
\hline \multirow[t]{3}{*}{ Corporate environmental ethics (CEE) } & CEE1 & The company has clear and concrete environmental policies & 0.781 & 0.695 \\
\hline & CEE2 & $\begin{array}{l}\text { The company's budget planning includes the concerns of environmental investment or } \\
\text { procurement }\end{array}$ & 0.751 & \\
\hline & CEE3 & $\begin{array}{l}\text { The company has integrated its environmental plan, vision, or mission to its marketing } \\
\text { events }\end{array}$ & 0.827 & \\
\hline \multirow[t]{5}{*}{ Stakeholder View (SV) } & SV1 & Our major competitors set environmental standards for their operations and products & 0.610 & 0.771 \\
\hline & SV2 & Our major competitors implement environmental strategies & 0.679 & \\
\hline & SV3 & $\begin{array}{l}\text { Environmental strategies we implement affect considerably our environmental reputation } \\
\text { with customers }\end{array}$ & 0.713 & \\
\hline & SV4 & Impact of our industry's products on the environment is of concern to our customers & 0.819 & \\
\hline & SV5 & $\begin{array}{l}\text { Impact of our industry's manufacturing operations on the environment is of concern to our } \\
\text { customers }\end{array}$ & 0.725 & \\
\hline \multirow[t]{4}{*}{ Market demand for green products (MD) } & MD1 & The segmentation of market & 0.851 & 0.821 \\
\hline & MD2 & Customers' requirements about green products & 0.816 & \\
\hline & MD3 & Price flexibility of demand for green products & 0.769 & \\
\hline & MD4 & Customer benefit for green products & 0.745 & \\
\hline
\end{tabular}

based on Lin et al. (2013). These items measured the market forces such as price flexibility, customer benefit and requirements which affect the demand for green products. These items along with their scales are listed in Table 1 along with the results of the confirmatory factor analysis for each of these constructs.

Green product innovation (GPRD) was measured by four items drawn and modified from a previous study by Chiou et al. (2011). The items measured the company's usage of environmental friendly materials that are non-toxic, easy to recycle and decompose, and non-polluting. The usage of eco-labeling was also measured. Green process innovation (GPRC) inquired about redesigning the manufacturing and production processes to meet environmental criteria, and four items were drawn from Chiou et al. (2011). The items sought to determine whether the operation processes consumed fewer resources (oil, gas, etc.), utilized renewable technology to save energy and time, and recycled materials to enhance environmental efficiency. The items of the GPRD and GRPC scales are listed in Table 2 along with the results of the confirmatory factor analysis.

Big Data Adoption (BDAD) was measured with three questions regarding Big Data Adoption/Acceptance based on Hazen et al. (2012). The items inquired about the incorporation of big data into the organizational structure and its effect on the respondent's job performance after his/her association with BDPA. Big Data Routinization (BDRT) was measured by five items adopted from Hazen et al. (2012). These 
Table 2

Green innovation practices.

\begin{tabular}{|c|c|c|c|c|}
\hline Construct & & Items & Factor loadings & Cronbach alpha \\
\hline \multirow[t]{5}{*}{ Green process innovation (GPRC) } & GPRC1 & Lower consumption of e.g. water, electricity, gas and petrol during production/use/disposal & 0.815 & 0.843 \\
\hline & GPRC2 & Recycle, reuse, and remanufacture materials or parts & 0.755 & \\
\hline & GPRC3 & Use of cleaner or renewable technology to make savings (such as energy, water, waste) & 0.765 & \\
\hline & GPRC4 & Redesign of production and operation processes to improve environmental efficiency & 0.747 & \\
\hline & GPRC5 & $\begin{array}{l}\text { Redesigning and improving products or services to meet new environmental criteria or } \\
\text { directives }\end{array}$ & 0.810 & \\
\hline \multirow[t]{4}{*}{ Green product innovation (GPRD) } & GPRD1 & The company uses less or non-polluting/toxic materials that are environmentally friendly & 0.807 & 0.839 \\
\hline & GPRD2 & The company uses materials that are easy to recycle, reuses, and decompose & 0.844 & \\
\hline & GPRD3 & The company recovers company's end-of-life products and recycling & 0.834 & \\
\hline & GPRD4 & The company uses eco-labeling & 0.809 & \\
\hline
\end{tabular}

items measured whether organizational procedures provide technical support, aid in hiring qualified people, and offer BDPA training opportunities. The allocation of BDPA budgeting and the presence of an organizational unit for BDPA were also measured.

Four items adopted from Hazen et al. (2012) and Liang et al. (2007) were used to measure Big Data Assimilation (BDAS). The items inquired about the BDPA's volume being used as a tool used in every department, its diversity being allocated for decision making, and its depth being functional in both managerial and operational areas. The items of the scales measuring BDAD, BDRT and BDAS are listed in Table 3 along with the results of the confirmatory factor analysis.

HR practices (HRP) were measured with five items based on a scale used by Astrachan and Kolenko (1994). The items inquired about overall HR management, employee review and manual, compensation plans, and job descriptions. Training practices (TRN) were measured with five items adopted from De Kok et al. (2006). These items measured in-house training of external and internal staff, intensifying old training programs and introducing new programs. Five measures regarding top management commitment (TMC) were adapted from a previous study by Liang et al. (2007). Management commitment refers to a company's support for environmental partnering and the acceptance of these ideas within the firm's culture. The vision for future collaboration was also measured in addition to organizational information sharing. The results of the confirmatory factor analysis and the items of the scales measuring HRP, TRN and TMC are listed in Table 4.

Environmental performance (EP) was measured with six items adopted from Lin et al. (2013). They measured reductions in hazardous waste and emissions, partnership with green suppliers, use of green materials, and compliance with the environmental criteria. Based on the scale of Chiou et al. (2011), Competitive Advantage (CA) was measured with seven items. The items sought to determine innovative skills, product quality, customer satisfaction, and production costs. Reductions in wastes and emissions, and consumption of fewer resources along with compliance to regulations were also measured. Organizational performance (OP) was measured by four items drawn from a previous study (Lin et al., 2013). These items measured the improvement in market position, sales volume, profit rate, and reputation. Items of the scales measuring the constructs EP, OP and CA and the results of the confirmatory factor analysis are shown in Table 5.

Organizational performance (OP) is assessed using both financial and nonfinancial measures, including profitability, market share, sales growth, overall performance, and stakeholder satisfaction (Lumpkin and Dess, 1996). In this study, a seven-item scale is used to measure performance. The respondents are asked to assess the performance of their organization relative to their competitors. The results of the confirmatory factor analysis and the items of the scales measuring EP, OP and CA are listed in Table 5.

Note that the items of the subscales listed in Tables 1-5 along with the results of the construct loadings and reliability indicate that the scale and its subscale items have high loadings ( $>0.5$ ), except for HRP4, and high reliability (Cronbach's $\alpha>0.7$ ).

\subsection{Data analysis}

The relationships in Fig. 1 were analyzed using partial least squares structural equation modeling (PLS-SEM) using the Smart PLS 3 software. PLS-SEM method was used instead of the traditional covariancebased technique and that is due to the fact that CB-SEM requires a large sample size (Kline, 2012). The partial least squares (PLS) approach to SEM (PLS-SEM) is a suitable, favorable method or instrument used for estimating a complex, hierarchical model representing the credibility and the methodology of soft modeling assumptions (Fosso Wamba et al., 2015; Papadopoulos et al., 2017). This explains the tendency of using PLS-SEM for complex models in the area of Big Data and business analytics quality (Fosso Wamba et al., 2015; Papadopoulos et al., 2017).

The first step in applying the PLS-SEM method is the outer model

Table 3

Big data.

\begin{tabular}{|c|c|c|c|c|}
\hline Construct & & Items & Factor loadings & Cronbach alpha \\
\hline \multirow[t]{3}{*}{ Big Data Adoption/Acceptance (BDAD) } & BDAD1 & You believe that embracing BDPA helps you enhance your job performance & 0.849 & 0.802 \\
\hline & BDAD2 & You and your colleagues associate with the BDPA systems & 0.847 & \\
\hline & BDAD3 & $\begin{array}{l}\text { You believe that an organizational and technical infrastructure exists to support use of the } \\
\text { BDPA }\end{array}$ & 0.842 & \\
\hline \multirow[t]{5}{*}{ Big Data Routinization (BDRT) } & BDRT1 & The BDPA process is supported by the normal budgeting & 0.714 & 0.790 \\
\hline & BDRT2 & There is a dedicated organizational unit for BDPA & 0.771 & \\
\hline & BDRT3 & Technical support can be obtained according to organizational procedures & 0.736 & \\
\hline & BDRT4 & Organization is able to hire and retain qualified people & 0.759 & \\
\hline & BDRT5 & $\begin{array}{l}\text { An organization offers opportunities for initial and/or recurring training regarding the } \\
\text { BDPA }\end{array}$ & 0.705 & \\
\hline \multirow[t]{4}{*}{ Big Data Assimilation (BDAS) } & BDAS1 & As an important tool in every department (volume) & 0.777 & 0.754 \\
\hline & BDAS2 & For decision making in your organization (diversity) & 0.813 & \\
\hline & BDAS3 & In the functional area of operation (depth) & 0.730 & \\
\hline & BDAS4 & In the functional area of management (depth) & 0.711 & \\
\hline
\end{tabular}


Table 4

Management commitment and HR practices.

\begin{tabular}{|c|c|c|c|c|}
\hline Construct & & Items & Factor loadings & Cronbach alpha \\
\hline \multirow[t]{5}{*}{ Top management commitment (TMC) } & TMC1 & $\begin{array}{l}\text { Expresses how green supply chain partnering will provide significant business benefits to the } \\
\text { firm }\end{array}$ & 0.824 & 0.842 \\
\hline & TMC2 & Expresses how green supply chain partnering will create a significant competitive arena & 0.847 & \\
\hline & TMC3 & Articulates vision for green supply chain collaboration & 0.804 & \\
\hline & TMC4 & Establishes the metrics to monitor green supply chain success through partnering & 0.816 & \\
\hline & TMC5 & Formulates strategy for organizational information sharing & 0.610 & \\
\hline \multirow[t]{5}{*}{ HR practices (HRP) } & HRP1 & Overall HR management & 0.737 & 0.800 \\
\hline & HRP2 & Formal and regular employee review process & 0.842 & \\
\hline & HRP3 & Compensation plans & 0.826 & \\
\hline & HRP4 & Written employee manual & 0.409 & \\
\hline & HRP5 & Written job descriptions & 0.774 & \\
\hline \multirow[t]{5}{*}{ Training practices (TRN) } & TRN1 & Training provided to employees & 0.779 & 0.774 \\
\hline & TRN2 & Recent introduction of formal training programs & 0.556 & \\
\hline & TRN3 & Recent intensification of existing training programs & 0.757 & \\
\hline & TRN4 & Formal in house training by internal staff & 0.763 & \\
\hline & TRN5 & Formal in house training by external staff & 0.754 & \\
\hline
\end{tabular}

Table 5

Performance and competitive advantage.

\begin{tabular}{|c|c|c|c|c|}
\hline Construct & & Items & Factor loadings & Cronbach alpha \\
\hline \multirow[t]{6}{*}{ Environmental performance (ENV) } & EP1 & Reduction of air emission & 0.792 & 0.908 \\
\hline & EP2 & Reduction of hazardous waste/scrap & 0.823 & \\
\hline & EP3 & Reduction in consumption of gasoline/fuel & 0.802 & \\
\hline & EP4 & Partnership with green organizations and suppliers & 0.856 & \\
\hline & EP5 & Improvement of environmental compliance & 0.873 & \\
\hline & EP6 & Use of environmental friendly material & 0.814 & \\
\hline \multirow[t]{7}{*}{ Competitive advantage (CA) } & CA1 & Reduction of hazardous waste, emissions, etc. & 0.740 & 0.897 \\
\hline & $\mathrm{CA} 2$ & Consume less resources, such as energy, water, electricity, gas and petrol, etc. & 0.759 & \\
\hline & CA3 & Compliance to environmental regulations & 0.818 & \\
\hline & CA4 & Customer satisfaction in relation to product design and development & 0.814 & \\
\hline & CA5 & Product design and innovation skill & 0.797 & \\
\hline & CA6 & Quality of product and service & 0.819 & \\
\hline & CA7 & Production cost & 0.755 & \\
\hline \multirow[t]{4}{*}{ Organizational performance (OP) } & OP1 & Market position improvement & 0.844 & 0.839 \\
\hline & OP2 & Enhancing sale volume & 0.853 & \\
\hline & OP3 & Enhancing the profit rate & 0.746 & \\
\hline & OP4 & Enhancing the reputation & 0.843 & \\
\hline
\end{tabular}

validation and the second step is the inner model path calculation. Validating the outer model consists of determining the convergent and discriminant validity as well as the reliability of the constructs (Wetzels et al., 2009). Once the model is validated, the inner model is fitted by calculating the path coefficients. The significance of the results are demonstrated through bootstrapping.

To examine the moderating effects, cluster analysis was employed to partition the companies involved in the study according to their management commitment and human resource practices. This technique clusters the company into groups based on certain criteria (DeSarbo et al., 1992; Kamakura and Wedel, 2000). Since these latent variables are measured by several indicators, the cluster analysis technique is one of the best grouping method. Once the clusters of companies were identified, a multi-group analysis was employed to determine the changes in the significance of the path coefficients among the various groups.

\subsection{Outer model analysis}

The unstandardized dataset using reflective scheme for all of the latent variables was employed to examine the model through PLS-SEM using SmartPLS3 software on. First, the convergent and discriminant validity of the latent constructs were examined. The convergent validity of all three constructs was supported as most factors loaded above the 0.7 threshold (See Tables 1-5). Therefore, the underlying construct explained a significant part of the variance in the observed variables (Hulland, 1999). Furthermore, the bootstrap test showed that all loadings were highly significant as all p-values for the bootstrap-based empirical $t$-tests were below 0.01 . Hence, we can conclude that the indicators significantly reflect on their underlying constructs.

The results showed average variance extracted (AVE) values of above 0.5 for all construct signifying that $>50 \%$ of the indicators' variance is captured by the constructs (see Table 6). Finally, the Cronbach's alpha and composite reliability values listed in Table 6 are well above the required 0.6 threshold (Nunnally and Bernstein, 1994) supporting the unidimensionality and reflective property of these construct and indicating high-scale reliability.

Discriminant validity was demonstrated by showing that the average shared variance of any construct and its indicators is greater than any of the shared variance with other constructs (Fornell and Larcker, 1981). Table 7 lists below demonstrated this fact since the values on the diagonal are greater than any value in their corresponding rows and columns.

\subsection{Inner model analysis}

The next step of the analysis examined the inner model. First, the tested model $R^{2}$ results demonstrated that an acceptable part of the variance of the constructs can be explained by the model $\left(R^{2}=0.540\right.$, $0.298,0.290,0.393,0.436$ and 0.494 for BDAS, GRPD, GPRC, EP, OP and CA constructs, respectively). These results were in agreement with the criteria suggested by Chin (1998); as such, the nomological validity of the model is considered satisfactory (Chin, 1998).

In the second step of the PLS-SEM method, the path coefficients 
Table 6

Discriminant validity of the constructs.

\begin{tabular}{|c|c|c|c|c|c|c|c|c|c|c|c|c|}
\hline & BDAD & BDAS & BDRT & $\mathrm{CA}$ & CEE & $\mathrm{EP}$ & OP & GPRC & GPRD & MD & SV & AVE \\
\hline BDAD & 0.846 & & & & & & & & & & & 0.716 \\
\hline BDAS & 0.504 & 0.759 & & & & & & & & & & 0.576 \\
\hline BDRT & 0.679 & 0.735 & 0.737 & & & & & & & & & 0.544 \\
\hline CA & 0.194 & 0.425 & 0.434 & 0.787 & & & & & & & & 0.619 \\
\hline CEE & 0.031 & 0.276 & 0.253 & 0.448 & 0.787 & & & & & & & 0.619 \\
\hline $\mathrm{EP}$ & 0.061 & 0.446 & 0.358 & 0.584 & 0.392 & 0.827 & & & & & & 0.684 \\
\hline OP & 0.181 & 0.498 & 0.499 & 0.678 & 0.444 & 0.699 & 0.822 & & & & & 0.676 \\
\hline GPRC & -0.037 & 0.229 & 0.217 & 0.452 & 0.410 & 0.609 & 0.526 & 0.824 & & & & 0.679 \\
\hline GPRD & 0.033 & 0.233 & 0.234 & 0.419 & 0.410 & 0.580 & 0.500 & 0.806 & 0.779 & & & 0.607 \\
\hline MD & 0.042 & 0.113 & 0.094 & 0.033 & 0.143 & 0.146 & 0.067 & 0.361 & 0.355 & 0.796 & & 0.634 \\
\hline SV & -0.043 & 0.125 & 0.109 & 0.111 & 0.193 & 0.171 & 0.146 & 0.374 & 0.396 & 0.621 & 0.712 & 0.507 \\
\hline
\end{tabular}

Table 7

Path coefficients estimates.

\begin{tabular}{llllll}
\hline Direct effect & Original sample & Sample mean & Std. dev. & t-Values & p-Values \\
\hline BDAD $\rightarrow$ BDRT & 0.679 & 0.680 & 0.032 & 21.231 & $0.000^{* *}$ \\
BDAS $\rightarrow$ CA & 0.100 & 0.098 & 0.063 & 1.583 & 0.114 \\
BDAS $\rightarrow$ OP & 0.390 & 0.388 & 0.057 & 6.826 & $0.000^{* *}$ \\
BDAS $\rightarrow$ GPRC & 0.096 & 0.095 & 0.055 & 1.756 & 0.079 \\
BDAS $\rightarrow$ GPRD & 0.099 & 0.098 & 0.060 & 1.660 & 0.097 \\
BDRT $\rightarrow$ BDAS & 0.735 & 0.735 & 0.040 & 18.186 & $0.000^{* *}$ \\
CEE $\rightarrow$ GPRC & 0.321 & 0.326 & 0.051 & 6.236 & $0.000^{* *}$ \\
CEE $\rightarrow$ GPRD & 0.317 & 0.324 & 0.052 & 6.115 & $0.000^{* *}$ \\
EP $\rightarrow$ CA & 0.156 & 0.158 & 0.071 & 2.215 & 0.027 \\
OP $\rightarrow$ CA & 0.475 & 0.477 & 0.076 & 6.224 & $0.000^{* *}$ \\
GPRC $\rightarrow$ CA & 0.087 & 0.082 & 0.077 & 1.127 & 0.260 \\
GPRC $\rightarrow$ EP & 0.403 & 0.399 & 0.098 & 4.108 & $0.000^{* *}$ \\
GPRC $\rightarrow$ OP & 0.305 & 0.298 & 0.114 & 2.676 & $0.008^{* *}$ \\
GPRD $\rightarrow$ CA & -0.003 & 0.003 & 0.079 & 0.042 & 0.967 \\
GPRD $\rightarrow$ EP & 0.255 & 0.263 & 0.102 & 2.496 & $0.013^{*}$ \\
GPRD $\rightarrow$ OP & 0.164 & 0.173 & 0.121 & 1.354 & 0.176 \\
MD $\rightarrow$ GPRC & 0.193 & 0.191 & 0.078 & 2.480 & $0.013^{*}$ \\
MD $\rightarrow$ GPRD & 0.160 & 0.160 & 0.085 & 1.891 & 0.059 \\
SV $\rightarrow$ GPRC & 0.180 & 0.191 & 0.078 & 2.308 & $0.021^{*}$ \\
SV $\rightarrow$ GPRD & 0.223 & 0.230 & 0.081 & 2.762 & $0.006^{* *}$ \\
\hline
\end{tabular}

* Significant at a 0.05 level.

** Significant at a 0.01 level.

were estimated. Assessing the structural model, the path coefficients among the drivers of green innovation, green innovation practices, big data, organizational and environmental performance as well as competitive advantage were computed. The results of both the inner model path coefficients and the outer loadings are depicted in Fig. 2 below. The bootstrapping method with 2000 iterations of resampling was used to examine these path coefficients (Davison and Hinkley, 1997). The results of the bootstrapping method are summarized in Table 7 below.

The path coefficients and the direct effect results of Table 7 below are used to examine $\mathrm{H} 1, \mathrm{H} 2$, and $\mathrm{H} 3$. First, $\mathrm{H} 1$ is examined by considering each of its sub-hypotheses:

H1a. Corporate environmental ethics positively influence green product innovation.

H1b. Stakeholders view positively influence green product innovation.

H1c. Market demand for green products positively influence green product innovation.

H1d. Corporate environmental ethics positively influence green process innovation.

H1e. Stakeholders view positively influence green process innovation.

H1f. Market demand for green products positively influence green process innovation.

The results indicate that corporate environmental ethics had positive significant direct effects on both, the green product and the process innovation (path coeffs. $=0.317$ and 0.321 ), thereby supporting $\mathrm{H} 1 \mathrm{a}$ and H1d. Similarly, the stakeholders' view was found to have a significant positive influence on green process innovation (path coeff. $=0.180$ ) and a stronger influence on green product innovation (path coeff. $=0.223$ ). These results support $\mathrm{H1b}$ and $\mathrm{H1}$ e. The results showed that the last green innovation driver, market demand for green product, had a positive significant influence on green process innovation (path coeff. $=0.193$ ), supporting $\mathrm{H} 2 \mathrm{c}$, and a marginal direct effect on green product innovation (path coeff. $=0.160$ ), leaving H2f unsupported.

Next, H2 is examined through each of its six sub-hypotheses:

H2a. Green product innovation positively influences competitive advantage.

H2b. Green product innovation positively influences organizational performance.

H2c. Green product innovation positively influences environmental performance.

H2d. Green process innovation positively influences competitive advantage.

H2e. Green process innovation positively influences organizational performance.

H2f. Green process innovation positively influences environmental performance.

The results indicate that green product innovation had a positive significant direct effect on the environmental performance (path coeff. $=0.255$ ), but no significant effect on neither organizational performance nor competitive advantage. These results support $\mathrm{H} 2 \mathrm{c}$, but leave $\mathrm{H} 2 \mathrm{a}$ and $\mathrm{H} 2 \mathrm{~b}$ unsupported. As for the green process innovation, no direct significant impact on competitive advantage was found. However, the green process innovation had a direct significant positive impact on both organizational and environmental performance (path coeffs. $=0.305$ and 0.403 ).

The last step of the direct effect analysis was to consider H3 stating that big data and predictive analysis positively influence green innovation practices, organizational performance and competitive advantage. The proposed conceptual model considers the utilization of big data technology in organizational operations as a three stage process, big data acceptance, routinization, and assimilation. Only the influence of Big Data Assimilation is considered since it is the final outcome this three stage process. We note that the results showed that adoption significantly impacts routinization (path coeff. $=0.679$ ) which in turns impacts assimilation (path coeff. $=0.735$ ), further justifying the restriction of examining the influence of Big Data Assimilation. Hence, the following sub-hypotheses of $\mathrm{H} 3$ are considered:

H3a. Big data and predictive analytics positively influence green process innovation. 


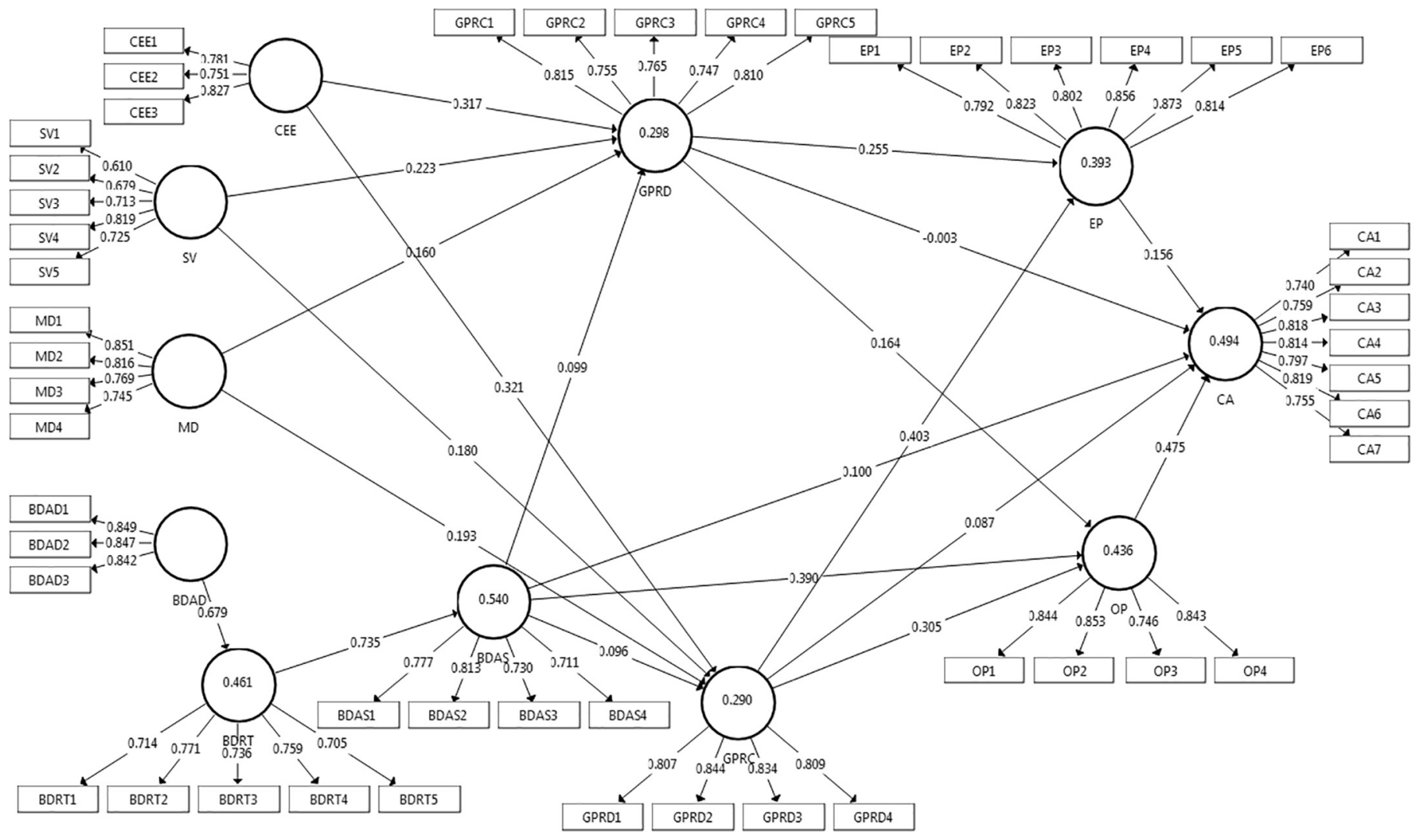

Fig. 2. Results of proposed model of green innovative and big data capabilities on performance and competitive advantage.

H3b. Big data and predictive analytics positively influence green product innovation.

H3c. Big data and predictive analytics positively organizational performance.

H3d. Big data and predictive analytics positively influence green product innovation.

The path coefficients and the direct effect results revealed that big data and predictive analytics, through adaption, routinization and assimilation, had a positive significant direct influence only on organizational performance (path coeff. $=0.390$ ), thereby supporting H3c.

The next step in the outer model analysis is to consider the indirect effects identified in H4. This hypothesis is examined through the following sub-hypothesis:

H4a. Corporate environmental ethics positively influences competitive advantage, organizational and environmental performance through green innovation practices.

H4b. Stakeholders view positively influences competitive advantage, organizational and environmental performance through green innovation practices.

H4c. Market demand for green products positively influences competitive advantage, organizational and environmental performance through green innovation practices.

H4d. Big data and predictive analytics positively influence competitive advantage, organizational and environmental performance through green innovation practices.

The path analysis results support the indirect effects of corporate environmental ethics on competitive advantage, organizational and environmental performance through green innovation practices (path coeffs. $=0.131,0.210$ and 0.150 ). Corporate environmental ethics showed the highest indirect effect on environmental performance.
Similarly, significant indirect effects of stakeholders view on competitive advantage, organizational and environmental performance through green innovation practices were found (path coeffs. $=0.079,0.129$ and 0.091). The highest indirect effect of stakeholders view was once again found to be on environmental performance. The indirect effects of market demand for green product on competitive advantage, organizational and environmental performance through green innovation practices were found significant (path coeffs. $=0.131,0.210$ and 0.150). These results support $\mathrm{H} 4 \mathrm{a}-\mathrm{H} 4 \mathrm{~b}$ and are further discussed in the Discussion Section. Finally, the path analysis results indicate that big data and predictive analytics had a significant indirect effect through green innovation practices on competitive advantage (path coeff. $=0.211$ ); however, no such effects on neither environmental nor organizational performance were detected (Table 8).

\subsection{Cluster analysis}

The last step in the path coefficients analysis was to examine H5. First, companies in the sample were grouped according to their HR practices, training and top management commitment. Then, multigroup analysis was employed to test for differences in the significance of the path coefficients among groups. The $K$-means clustering method is used to group the companies. First, the number of clusters is specified, and cluster seeds were randomly chosen using SPSS 24. Subsequently, each observation was assigned to one cluster based on similarity. By varying the numbers of clusters tested (i.e., two, three, and four), the results of the $K$-means procedure for HRP indicated a threecluster solution which is valid and statistically significant $(\mathrm{p}<0.001$; see Table 9 below). The ANOVA tests revealed that all items contributed to differentiating the two clusters $(\mathrm{p}<0.001)$. The first and third clusters (57 and 41 observations) appeared to have lower mean scores on HR items. These two clusters were combined and labeled "Low HR Practices." The second cluster (117 observations) was found to have the highest mean scores on the HR items, suggesting that this 
Table 8

Indirect effects.

\begin{tabular}{|c|c|c|c|c|c|}
\hline & $\begin{array}{l}\text { Original } \\
\text { sample }\end{array}$ & $\begin{array}{l}\text { Sample } \\
\text { mean }\end{array}$ & $\begin{array}{l}\text { Standard } \\
\text { deviation }\end{array}$ & $t$-Values & p-Values \\
\hline $\mathrm{BDAD} \rightarrow \mathrm{BDAS}$ & 0.499 & 0.500 & 0.039 & 12.795 & $0.000^{* *}$ \\
\hline $\mathrm{BDAD} \rightarrow \mathrm{CA}$ & 0.162 & 0.162 & 0.036 & 4.564 & $0.000^{* * *}$ \\
\hline $\mathrm{BDAD} \rightarrow \mathrm{EP}$ & 0.032 & 0.033 & 0.019 & 1.714 & 0.087 \\
\hline $\mathrm{BDAD} \rightarrow \mathrm{OP}$ & 0.217 & 0.217 & 0.036 & 6.031 & $0.000^{* * *}$ \\
\hline BDAD $\rightarrow$ GPRC & 0.048 & 0.048 & 0.028 & 1.703 & 0.089 \\
\hline $\mathrm{BDAD} \rightarrow \mathrm{GPRD}$ & 0.050 & 0.049 & 0.031 & 1.609 & 0.108 \\
\hline $\mathrm{BDAS} \rightarrow \mathrm{CA}$ & 0.225 & 0.226 & 0.045 & 4.951 & $0.000^{* * *}$ \\
\hline $\mathrm{BDAS} \rightarrow \mathrm{EP}$ & 0.064 & 0.066 & 0.036 & 1.781 & 0.075 \\
\hline $\mathrm{BDAS} \rightarrow \mathrm{OP}$ & 0.046 & 0.045 & 0.025 & 1.790 & 0.074 \\
\hline $\mathrm{BDRT} \rightarrow \mathrm{EP}$ & 0.239 & 0.238 & 0.049 & 4.833 & $0.000^{* *}$ \\
\hline $\mathrm{BDRT} \rightarrow \mathrm{CA}$ & 0.047 & 0.048 & 0.027 & 1.756 & 0.079 \\
\hline $\mathrm{BDRT} \rightarrow \mathrm{OP}$ & 0.320 & 0.319 & 0.049 & 6.544 & $0.000^{* * *}$ \\
\hline BDRT $\rightarrow$ GPRC & 0.071 & 0.070 & 0.041 & 1.735 & 0.083 \\
\hline $\mathrm{BDRT} \rightarrow \mathrm{GPRD}$ & 0.073 & 0.072 & 0.044 & 1.642 & 0.101 \\
\hline $\mathrm{CEE} \rightarrow \mathrm{CA}$ & 0.131 & 0.135 & 0.030 & 4.355 & $0.000^{* * *}$ \\
\hline $\mathrm{CEE} \rightarrow \mathrm{EP}$ & 0.210 & 0.215 & 0.036 & 5.851 & $0.000^{* *}$ \\
\hline $\mathrm{CEE} \rightarrow \mathrm{OP}$ & 0.150 & 0.154 & 0.029 & 5.153 & $0.000^{* * *}$ \\
\hline $\mathrm{GPRC} \rightarrow \mathrm{CA}$ & 0.208 & 0.207 & 0.072 & 2.904 & $0.004^{* * *}$ \\
\hline $\mathrm{GPRD} \rightarrow \mathrm{CA}$ & 0.118 & 0.122 & 0.065 & 1.803 & 0.072 \\
\hline $\mathrm{MD} \rightarrow \mathrm{CA}$ & 0.075 & 0.076 & 0.033 & 2.265 & $0.024^{*}$ \\
\hline $\mathrm{MD} \rightarrow \mathrm{EP}$ & 0.118 & 0.119 & 0.052 & 2.277 & $0.023^{*}$ \\
\hline $\mathrm{MD} \rightarrow \mathrm{OP}$ & 0.085 & 0.085 & 0.036 & 2.356 & 0.019 \\
\hline $\mathrm{SV} \rightarrow \mathrm{CA}$ & 0.079 & 0.082 & 0.033 & 2.348 & $0.019 *$ \\
\hline $\mathrm{SV} \rightarrow \mathrm{EP}$ & 0.129 & 0.136 & 0.049 & 2.636 & $0.008^{* *}$ \\
\hline $\mathrm{SV} \rightarrow \mathrm{OP}$ & 0.091 & 0.095 & 0.039 & 2.371 & $0.018^{* * *}$ \\
\hline
\end{tabular}

* Significant at a 0.05 level.

** Significant at a 0.01 level.

group is formed by companies with higher HR practices; this cluster was labeled "High HR Practices." Note that only four out of the five HRP items were used in the cluster analysis since HRP4 resulted in a low factor loading of 0.409 , see Table 4 . Similar analysis was conducted for training resulting in three clusters, two of which were combined to form the "Low Training" group with 86 observations. The other group with 129 observations was labeled "High Training". The items of top management commitment construct resulted in two groups, "High Top Management Commitment" with 119 observations and "Low Top Management Commitment" with 95 observations.

\subsection{Multi-group analysis}

The final step was to compare the results from the model among the groups identified in the cluster analysis. Multi-group $t$-test analysis was employed in Smart PLS 3.1. The significance of the path coefficients and the confidence intervals were generated using bootstrap sampling techniques. Based on the above clustering, a multi-group analysis was conducted to determine whether the significance of the relationships in the above model (Fig. 2) differ among companies with low and high HR practices. The multi-group analysis is summarized in Tables 10 and 11 below.

The direct effect results of Table 10 showed that the two groups exhibit differences in the significance of corporate environmental ethics on green process innovation, green product innovation on environmental and organizational performance, and market demand for green products on green process innovation. In all cases, the influence was significant for companies with high HR practices and non-significant for the companies with low HR practices. These results provide evidence to support H5. Also, the path coefficients analysis revealed that a difference in the significance of the direct effect of environmental performance on competitive advantage. The effect was significant for companies with lower HR practices and non-significant for those with high HR practices. This result that seems surprising at first indicates that through better environmental performance, companies with low HR practices may attain competitive advantage, most likely of the environmental type and not the economic type. On the other hand, companies with established HR practices attain a more balanced competitive advantage through a combination of better environmental and organizational performance.

The indirect effect results of Table 11 revealed that the two group exhibit differences in the significance of the effect of corporate environmental ethics on environmental and organizational performance as well as competitive advantage, green products innovation on competitive advantage, demand for green product on environmental and organizational performance, and stakeholders view on organizational performance. In all cases, the influence was significant for companies with high HR practices and non-significant for the companies with low HR practices. These results provide further evidence to support H5.

Next, the above clustering of companies based on training was used to conduct the multi-group analysis. The results are listed in Tables 12 and 13 below. The direct effect results of Table 12 indicated that differences among the two groups were found in the significance of the direct effect of green product innovation on environmental performance, and stakeholders view on both, the green product and process innovation. This suggests that higher level training is required for green product innovation on environmental performance, and pressure from stakeholders to influence green innovation practices. Without proper training, green product innovation may not translate into better environmental performance, and with higher pressure from stakeholders, companies may still fail to engage in green innovation practices. On the

Table 9

Cluster analysis.

\begin{tabular}{|c|c|c|c|c|c|c|c|c|c|}
\hline & \multicolumn{3}{|c|}{ Final cluster centers } & \multicolumn{6}{|l|}{ ANOVA } \\
\hline & 1 & 2 & 3 & Mean square & $\mathrm{df}$ & Mean square & df & F-Values & p-Values \\
\hline & $\mathrm{n}=57$ & $\mathrm{n}=117$ & $\mathrm{n}=41$ & HR practices & & & & & \\
\hline HRP1 & 3 & 4 & 3 & 34.918 & 2 & 0.316 & 212 & 110.67 & 0.0000 \\
\hline HRP2 & 3 & 5 & 2 & 121.593 & 2 & 0.387 & 212 & 314.168 & 0.0000 \\
\hline HRP3 & 3 & 4 & 2 & 40.209 & 2 & 0.712 & 212 & 56.486 & 0.0000 \\
\hline HRP5 & $\begin{array}{l}4 \\
n=129\end{array}$ & $\begin{array}{l}5 \\
\mathrm{n}=25\end{array}$ & $\begin{array}{l}3 \\
\mathrm{n}=61\end{array}$ & $\begin{array}{l}75.739 \\
\text { Training }\end{array}$ & 2 & 0.413 & 212 & 183.546 & 0.0000 \\
\hline TRN1 & 4 & 2 & 3 & 21.965 & 2 & 0.46 & 212 & 47.766 & 0.0000 \\
\hline TRN3 & 4 & 2 & 2 & 51.249 & 2 & 0.549 & 212 & 93.373 & 0.0000 \\
\hline TRN4 & 4 & 3 & 2 & 85.937 & 2 & 0.509 & 212 & 168.889 & 0.0000 \\
\hline \multirow[t]{2}{*}{ TRN5 } & 4 & 2 & 3 & 28.386 & 2 & 0.373 & 212 & 76.063 & 0.0000 \\
\hline & $\mathrm{n}=119$ & $\mathrm{n}=95$ & & Top managem & nitn & & & & \\
\hline TMC1 & 4 & 3 & & 69.813 & 1 & 0.391 & 212 & 178.538 & 0.0000 \\
\hline TMC2 & 4 & 2 & & 216.953 & 1 & 0.503 & 212 & 431.698 & 0.0000 \\
\hline TMC3 & 4 & 3 & & 111.405 & 1 & 0.468 & 212 & 238.132 & 0.0000 \\
\hline TMC4 & 4 & 2 & & 116.067 & 1 & 0.527 & 212 & 220.188 & 0.0000 \\
\hline TMC5 & 4 & 3 & & 66.795 & 1 & 0.527 & 212 & 126.677 & 0.0000 \\
\hline
\end{tabular}


Table 10

Multi-group analysis for HRP (direct effects).

\begin{tabular}{|c|c|c|c|c|c|c|c|c|}
\hline \multirow[t]{2}{*}{ HRP direct } & \multicolumn{4}{|l|}{ High HRP } & \multicolumn{4}{|l|}{ Low HRP } \\
\hline & Path coeff. & STDEV & $t$-Values & p-Values & Path coeff. & STDEV & $t$-Values & p-Values \\
\hline $\mathrm{BDAD} \rightarrow \mathrm{BDRT}$ & 0.608 & 0.049 & 12.453 & 0.000 & 0.748 & 0.042 & 17.768 & 0.000 \\
\hline $\mathrm{BDAS} \rightarrow \mathrm{CA}$ & 0.189 & 0.078 & 2.408 & 0.016 & 0.066 & 0.114 & 0.580 & 0.562 \\
\hline $\mathrm{BDAS} \rightarrow \mathrm{OP}$ & 0.245 & 0.078 & 3.164 & 0.002 & 0.462 & 0.079 & 5.855 & 0.000 \\
\hline BDAS $\rightarrow$ GPRC & -0.001 & 0.072 & 0.012 & 0.991 & 0.169 & 0.081 & 2.096 & 0.036 \\
\hline BDAS $\rightarrow$ GPRD & 0.106 & 0.076 & 1.402 & 0.161 & 0.065 & 0.092 & 0.704 & 0.482 \\
\hline BDRT $\rightarrow$ BDAS & 0.675 & 0.068 & 9.988 & 0.000 & 0.746 & 0.055 & 13.655 & 0.000 \\
\hline $\mathrm{CEE} \rightarrow \mathrm{GPRC}$ & 0.248 & 0.081 & 3.059 & 0.002 & 0.147 & 0.087 & 1.697 & 0.090 \\
\hline $\mathrm{CEE} \rightarrow \mathrm{GPRD}$ & 0.244 & 0.088 & 2.778 & 0.006 & 0.228 & 0.096 & 2.389 & 0.017 \\
\hline $\mathrm{EP} \rightarrow \mathrm{CA}$ & 0.026 & 0.116 & 0.224 & 0.823 & 0.224 & 0.097 & 2.304 & 0.021 \\
\hline $\mathrm{OP} \rightarrow \mathrm{CA}$ & 0.517 & 0.102 & 5.048 & 0.000 & 0.334 & 0.126 & 2.644 & 0.008 \\
\hline $\mathrm{GPRC} \rightarrow \mathrm{CA}$ & 0.104 & 0.126 & 0.828 & 0.408 & 0.042 & 0.117 & 0.359 & 0.719 \\
\hline $\mathrm{GPRC} \rightarrow \mathrm{EP}$ & 0.224 & 0.111 & 2.008 & 0.045 & 0.360 & 0.151 & 2.383 & 0.017 \\
\hline $\mathrm{GPRC} \rightarrow \mathrm{OP}$ & 0.219 & 0.135 & 1.624 & 0.105 & 0.203 & 0.156 & 1.300 & 0.194 \\
\hline $\mathrm{GPRD} \rightarrow \mathrm{CA}$ & 0.100 & 0.129 & 0.780 & 0.436 & -0.022 & 0.123 & 0.177 & 0.860 \\
\hline $\mathrm{GPRD} \rightarrow \mathrm{EP}$ & 0.549 & 0.107 & 5.129 & 0.000 & 0.115 & 0.156 & 0.741 & 0.459 \\
\hline $\mathrm{GPRD} \rightarrow \mathrm{OP}$ & 0.398 & 0.143 & 2.795 & 0.005 & 0.069 & 0.170 & 0.405 & 0.685 \\
\hline $\mathrm{MD} \rightarrow \mathrm{GPRC}$ & 0.266 & 0.112 & 2.366 & 0.018 & 0.196 & 0.117 & 1.681 & 0.093 \\
\hline $\mathrm{MD} \rightarrow \mathrm{GPRD}$ & 0.222 & 0.116 & 1.916 & 0.055 & 0.102 & 0.134 & 0.759 & 0.448 \\
\hline $\mathrm{SV} \rightarrow \mathrm{GPRC}$ & 0.263 & 0.106 & 2.478 & 0.013 & 0.244 & 0.125 & 1.951 & 0.051 \\
\hline $\mathrm{SV} \rightarrow \mathrm{GPRD}$ & 0.265 & 0.105 & 2.520 & 0.012 & 0.323 & 0.121 & 2.667 & 0.008 \\
\hline
\end{tabular}

Table 11

Multi-group analysis for HRP (indirect effects).

\begin{tabular}{|c|c|c|c|c|c|c|c|c|}
\hline \multirow[t]{2}{*}{ HRP indirect } & \multicolumn{4}{|l|}{ High HRP } & \multicolumn{4}{|l|}{ Low HRP } \\
\hline & Path coeff. & STDEV & $t$-Values & p-Values & Path coeff. & STDEV & $t$-Values & p-Values \\
\hline BDAS $\rightarrow$ CA & 0.161 & 0.054 & 2.967 & 0.003 & 0.188 & 0.070 & 2.701 & 0.007 \\
\hline $\mathrm{BDAS} \rightarrow \mathrm{EP}$ & 0.058 & 0.058 & 0.999 & 0.318 & 0.068 & 0.048 & 1.436 & 0.151 \\
\hline $\mathrm{BDAS} \rightarrow \mathrm{OP}$ & 0.042 & 0.050 & 0.849 & 0.396 & 0.039 & 0.032 & 1.201 & 0.230 \\
\hline $\mathrm{CEE} \rightarrow \mathrm{CA}$ & 0.134 & 0.049 & 2.702 & 0.007 & 0.034 & 0.036 & 0.942 & 0.346 \\
\hline $\mathrm{CEE} \rightarrow \mathrm{EP}$ & 0.190 & 0.064 & 2.980 & 0.003 & 0.079 & 0.050 & 1.584 & 0.113 \\
\hline $\mathrm{CEE} \rightarrow \mathrm{OP}$ & 0.152 & 0.050 & 3.013 & 0.003 & 0.046 & 0.038 & 1.218 & 0.223 \\
\hline $\mathrm{GPRC} \rightarrow \mathrm{CA}$ & 0.119 & 0.081 & 1.470 & 0.142 & 0.149 & 0.079 & 1.874 & 0.061 \\
\hline $\mathrm{GPRD} \rightarrow \mathrm{CA}$ & 0.220 & 0.093 & 2.374 & 0.018 & 0.049 & 0.075 & 0.653 & 0.514 \\
\hline $\mathrm{MD} \rightarrow \mathrm{CA}$ & 0.130 & 0.069 & 1.885 & 0.060 & 0.040 & 0.036 & 1.119 & 0.263 \\
\hline $\mathrm{MD} \rightarrow \mathrm{EP}$ & 0.181 & 0.089 & 2.038 & 0.042 & 0.082 & 0.062 & 1.335 & 0.182 \\
\hline $\mathrm{MD} \rightarrow \mathrm{OP}$ & 0.147 & 0.070 & 2.087 & 0.037 & 0.047 & 0.041 & 1.144 & 0.253 \\
\hline $\mathrm{SV} \rightarrow \mathrm{CA}$ & 0.143 & 0.058 & 2.479 & 0.013 & 0.055 & 0.046 & 1.204 & 0.229 \\
\hline $\mathrm{SV} \rightarrow \mathrm{EP}$ & 0.204 & 0.079 & 2.584 & 0.010 & 0.125 & 0.063 & 1.978 & 0.048 \\
\hline $\mathrm{SV} \rightarrow \mathrm{OP}$ & 0.163 & 0.069 & 2.361 & 0.018 & 0.072 & 0.048 & 1.503 & 0.133 \\
\hline
\end{tabular}

Table 12

Multi-group analysis for training practices (direct effects).

\begin{tabular}{|c|c|c|c|c|c|c|c|c|}
\hline \multirow[t]{2}{*}{ TRN direct } & \multicolumn{4}{|c|}{ High training practices } & \multicolumn{4}{|c|}{ Low training practices } \\
\hline & Path coeff. & STDEV & $t$-Values & p-Values & Path coeff. & STDEV & $t$-Values & p-Values \\
\hline $\mathrm{BDAD} \rightarrow \mathrm{BDRT}$ & 0.632 & 0.040 & 15.643 & 0.000 & 0.774 & 0.047 & 16.421 & 0.000 \\
\hline $\mathrm{BDAS} \rightarrow \mathrm{CA}$ & 0.131 & 0.082 & 1.609 & 0.108 & 0.096 & 0.120 & 0.796 & 0.426 \\
\hline BDAS $\rightarrow$ OP & 0.208 & 0.069 & 2.989 & 0.003 & 0.577 & 0.063 & 9.102 & 0.000 \\
\hline BDAS $\rightarrow$ GPRC & 0.064 & 0.073 & 0.876 & 0.381 & 0.121 & 0.092 & 1.318 & 0.188 \\
\hline BDAS $\rightarrow$ GPRD & 0.104 & 0.085 & 1.224 & 0.221 & 0.127 & 0.106 & 1.198 & 0.231 \\
\hline BDRT $\rightarrow$ BDAS & 0.692 & 0.060 & 11.549 & 0.000 & 0.760 & 0.054 & 14.140 & 0.000 \\
\hline $\mathrm{CEE} \rightarrow \mathrm{GPRC}$ & 0.165 & 0.066 & 2.494 & 0.013 & 0.290 & 0.093 & 3.128 & 0.002 \\
\hline $\mathrm{CEE} \rightarrow \mathrm{GPRD}$ & 0.257 & 0.072 & 3.568 & 0.000 & 0.169 & 0.096 & 1.754 & 0.080 \\
\hline $\mathrm{EP} \rightarrow \mathrm{CA}$ & 0.182 & 0.098 & 1.860 & 0.063 & 0.102 & 0.128 & 0.798 & 0.425 \\
\hline $\mathrm{OP} \rightarrow \mathrm{CA}$ & 0.455 & 0.103 & 4.415 & 0.000 & 0.480 & 0.140 & 3.425 & 0.001 \\
\hline $\mathrm{GPRC} \rightarrow \mathrm{CA}$ & 0.086 & 0.104 & 0.829 & 0.407 & 0.054 & 0.132 & 0.412 & 0.680 \\
\hline $\mathrm{GPRC} \rightarrow \mathrm{EP}$ & 0.346 & 0.164 & 2.105 & 0.035 & 0.437 & 0.159 & 2.747 & 0.006 \\
\hline $\mathrm{GPRC} \rightarrow$ OP & 0.308 & 0.194 & 1.589 & 0.112 & 0.174 & 0.173 & 1.006 & 0.315 \\
\hline $\mathrm{GPRD} \rightarrow \mathrm{CA}$ & 0.002 & 0.128 & 0.018 & 0.986 & -0.022 & 0.125 & 0.173 & 0.862 \\
\hline GPRD $\rightarrow$ EP & 0.358 & 0.171 & 2.096 & 0.036 & 0.094 & 0.174 & 0.541 & 0.589 \\
\hline GPRD $\rightarrow$ OP & 0.326 & 0.209 & 1.561 & 0.119 & 0.035 & 0.177 & 0.200 & 0.841 \\
\hline $\mathrm{MD} \rightarrow \mathrm{GPRC}$ & 0.067 & 0.128 & 0.522 & 0.602 & 0.359 & 0.119 & 3.016 & 0.003 \\
\hline $\mathrm{MD} \rightarrow \mathrm{GPRD}$ & 0.033 & 0.148 & 0.224 & 0.823 & 0.300 & 0.121 & 2.480 & 0.013 \\
\hline $\mathrm{SV} \rightarrow \mathrm{GPRC}$ & 0.483 & 0.111 & 4.350 & 0.000 & 0.014 & 0.121 & 0.119 & 0.906 \\
\hline $\mathrm{SV} \rightarrow \mathrm{GPRD}$ & 0.444 & 0.130 & 3.409 & 0.001 & 0.173 & 0.122 & 1.415 & 0.157 \\
\hline
\end{tabular}


Table 13

Multi-group analysis for training practices (indirect effects).

\begin{tabular}{|c|c|c|c|c|c|c|c|c|}
\hline \multirow[t]{2}{*}{ TRN indirect } & \multicolumn{4}{|l|}{ High HRP } & \multicolumn{4}{|l|}{ Low HRP } \\
\hline & Path coeff. & STDEV & $t$-Values & p-Values & Path coeff. & STDEV & $t$-Values & p-Values \\
\hline BDAS $\rightarrow$ CA & 0.135 & 0.051 & 2.669 & 0.008 & 0.300 & 0.090 & 3.331 & 0.001 \\
\hline $\mathrm{BDAS} \rightarrow \mathrm{EP}$ & 0.059 & 0.055 & 1.080 & 0.280 & 0.065 & 0.053 & 1.214 & 0.225 \\
\hline $\mathrm{BDAS} \rightarrow \mathrm{OP}$ & 0.053 & 0.050 & 1.067 & 0.286 & 0.026 & 0.027 & 0.943 & 0.346 \\
\hline $\mathrm{CEE} \rightarrow \mathrm{CA}$ & 0.041 & 0.039 & 1.047 & 0.295 & 0.049 & 0.042 & 1.184 & 0.236 \\
\hline $\mathrm{CEE} \rightarrow \mathrm{EP}$ & 0.181 & 0.058 & 3.137 & 0.002 & 0.458 & 0.059 & 7.722 & 0.000 \\
\hline $\mathrm{CEE} \rightarrow \mathrm{OP}$ & 0.044 & 0.051 & 0.859 & 0.390 & 0.092 & 0.071 & 1.287 & 0.198 \\
\hline $\mathrm{GPRC} \rightarrow \mathrm{CA}$ & 0.072 & 0.061 & 1.181 & 0.238 & 0.096 & 0.081 & 1.182 & 0.237 \\
\hline $\mathrm{GPRD} \rightarrow \mathrm{CA}$ & 0.103 & 0.045 & 2.286 & 0.022 & 0.054 & 0.038 & 1.434 & 0.152 \\
\hline $\mathrm{MD} \rightarrow \mathrm{CA}$ & 0.149 & 0.047 & 3.174 & 0.002 & 0.143 & 0.062 & 2.311 & 0.021 \\
\hline $\mathrm{MD} \rightarrow \mathrm{EP}$ & 0.135 & 0.050 & 2.700 & 0.007 & 0.056 & 0.039 & 1.447 & 0.148 \\
\hline $\mathrm{MD} \rightarrow \mathrm{OP}$ & 0.203 & 0.120 & 1.694 & 0.090 & 0.128 & 0.110 & 1.170 & 0.242 \\
\hline $\mathrm{SV} \rightarrow \mathrm{CA}$ & 0.213 & 0.100 & 2.128 & 0.033 & 0.027 & 0.104 & 0.257 & 0.798 \\
\hline $\mathrm{SV} \rightarrow \mathrm{EP}$ & 0.026 & 0.070 & 0.375 & 0.707 & 0.067 & 0.037 & 1.808 & 0.071 \\
\hline $\mathrm{SV} \rightarrow \mathrm{OP}$ & 0.035 & 0.095 & 0.368 & 0.713 & 0.185 & 0.070 & 2.635 & 0.008 \\
\hline
\end{tabular}

other hand, differences in the effects of market demand on green and process innovation were detected. The effects were significant for companies with low training practices, and not significant for companies with high training practices. This indicates that companies with low training practices tend to react more to market demand for green product and may benefit in terms of environmental performance. However, companies with higher training practices may not react to the demand for green product unless balanced benefits are achieved.

The indirect effect results of Table 13 revealed that there are differences in the significance of the effect of green products innovation on competitive advantage, demand for green product on environmental performance, stakeholders view on organizational performance and competitive advantage. These effects were significant for companies with high training practices and non-significant for the companies with lower training practices. Hence, training is required in order for the demand for green product to have a significant positive impact on environmental performance through green innovation practices, and for stakeholders view to positively influence organizational performance and competitive advantage through these green innovation practices. The results also showed that the indirect effect of stakeholders' view on organizational performance is significant for companies with lower training practices and nonsignificant for the other group. Hence, under pressure from stakeholders, companies with low training practices may achieve some organizational performance. However, unlike companies with higher level of competitive advantage may not be attained under such pressure.

The final step in the multi-group analysis was to examine differences in the significance of the relationships among companies with low and high top management commitment to green practices. The multigroup analysis is summarized in Tables 14 and 15 below.

The direct effect results of Table 14 showed that the two groups exhibit differences in the significance of the direct effect of big data and predicative analytics and market demand for green product on green process innovation, corporate environmental ethics on green product innovation, and stakeholders view on green product and process innovation. In all these cases, the influence was significant for companies with high top management commitment and non-significant for those with lower commitment. These results suggest that under pressure from stakeholders, green innovation practices are achieved whenever top management is more committed to green practices. Moreover, for companies with high management commitment, Big Data Assimilation through adoption and routinization tend to be more incorporated and spread across the organization's processes in general and green processes in particular. Also, green product innovation in such companies is influenced by their environmental ethics. Finally, the direct effect results indicate that, unlike companies with low top management commitment, green product innovation is not influenced by green product demand when commitment is high.

Examining the indirect effects listed in Table 15, the only difference was found in the significance of the corporate environmental ethics on organizational performance. The effect was significant for companies with high top management commitment and non-significant for companies with lower commitment. This result suggests that when top management is committed to green practices, environmental ethics influence organizational performance through green innovation practices.

\section{Discussion}

\subsection{Theoretical contributions}

Based on the extant literature, firms are pressured to identify business practices that enhance not only their competitive advantage and economic performance, but also their environmental performance (Chiou et al., 2011). Hence, aggressively pursuing the adoption and implementation of environmental friendly activities, such as green innovation practices, is becoming crucial as firms are faced with internal and external pressure to engage in such activities. The adoption of green product innovation and green process innovation involve reduction in consumption of energy and pollution emission, recycling of wastes, sustainable utilization of resources, and green product designs. Understanding the drivers of green innovation practices is essential as indicated by several recent studies. The benefits of adopting environmental friendly activities have been examined in the literature. In order to overcome the technological challenges of green innovation, previous studies have suggested that higher firm performance and competitive advantage through green practices may not be attained without management commitment, proper HR practices, and use of large scale data (Chatterjee et al., 2002; Gunasekaran et al., 2017).

This study determines the importance of the drivers of green innovation and its influence on competitive advantage, environmental and organizational performance. Several drivers have been identified in the literature which include corporate environmental ethics, stakeholders view and market demand (Chang, 2011; Lin et al., 2013; Weng et al., 2015; Zailani et al., 2015). In addition, the role of large scale data, management commitment, and human resource practices were examined as they play an important role to overcome the technological challenges, achieve competitive advantage, and enhance the economic and environmental performance. A holistic model that depicts and examines the relationships among green innovation, its drivers, as well as factors that help overcome the technological challenges and influence the performance and competitive advantage of the firm was developed 
Table 14

Multi-group analysis for top management commitment (direct effects).

\begin{tabular}{|c|c|c|c|c|c|c|c|c|}
\hline \multirow[t]{2}{*}{ TMC direct } & \multicolumn{4}{|l|}{ High HRP } & \multicolumn{4}{|l|}{ Low HRP } \\
\hline & Path coeff. & STDEV & $t$-Values & p-Values & Path coeff. & STDEV & $t$-Values & p-Values \\
\hline $\mathrm{BDAD} \rightarrow \mathrm{BDRT}$ & 0.748 & 0.746 & 17.283 & 0.000 & 0.743 & 0.047 & 15.831 & 0.000 \\
\hline $\mathrm{BDAS} \rightarrow \mathrm{CA}$ & 0.066 & 0.071 & 0.584 & 0.559 & 0.077 & 0.124 & 0.623 & 0.533 \\
\hline $\mathrm{BDAS} \rightarrow \mathrm{OP}$ & 0.462 & 0.578 & 6.220 & 0.000 & 0.572 & 0.075 & 7.648 & 0.000 \\
\hline BDAS $\rightarrow$ GPRC & 0.169 & 0.030 & 2.152 & 0.032 & 0.031 & 0.095 & 0.329 & 0.742 \\
\hline BDAS $\rightarrow$ GPRD & 0.065 & 0.056 & 0.699 & 0.485 & 0.058 & 0.086 & 0.680 & 0.497 \\
\hline BDRT $\rightarrow$ BDAS & 0.746 & 0.763 & 14.098 & 0.000 & 0.762 & 0.053 & 14.376 & 0.000 \\
\hline $\mathrm{CEE} \rightarrow \mathrm{GPRC}$ & 0.147 & 0.097 & 1.817 & 0.069 & 0.105 & 0.142 & 0.738 & 0.461 \\
\hline $\mathrm{CEE} \rightarrow \mathrm{GPRD}$ & 0.228 & 0.085 & 2.520 & 0.012 & 0.088 & 0.112 & 0.785 & 0.432 \\
\hline $\mathrm{EP} \rightarrow \mathrm{CA}$ & 0.224 & 0.305 & 2.321 & 0.020 & 0.294 & 0.106 & 2.769 & 0.006 \\
\hline $\mathrm{OP} \rightarrow \mathrm{CA}$ & 0.334 & 0.326 & 2.672 & 0.008 & 0.324 & 0.124 & 2.615 & 0.009 \\
\hline $\mathrm{GPRC} \rightarrow \mathrm{CA}$ & 0.042 & -0.011 & 0.362 & 0.718 & 0.007 & 0.124 & 0.059 & 0.953 \\
\hline $\mathrm{GPRC} \rightarrow \mathrm{EP}$ & 0.360 & 0.371 & 2.444 & 0.015 & 0.410 & 0.194 & 2.113 & 0.035 \\
\hline $\mathrm{GPRC} \rightarrow$ OP & 0.203 & 0.060 & 1.273 & 0.203 & 0.072 & 0.177 & 0.406 & 0.685 \\
\hline $\mathrm{GPRD} \rightarrow \mathrm{CA}$ & -0.022 & -0.029 & 0.185 & 0.853 & -0.045 & 0.137 & 0.332 & 0.740 \\
\hline $\mathrm{GPRD} \rightarrow \mathrm{EP}$ & 0.115 & -0.210 & 0.749 & 0.454 & -0.252 & 0.196 & 1.288 & 0.198 \\
\hline GPRD $\rightarrow$ OP & 0.069 & -0.179 & 0.404 & 0.686 & -0.189 & 0.180 & 1.050 & 0.294 \\
\hline $\mathrm{MD} \rightarrow \mathrm{GPRC}$ & 0.196 & 0.413 & 1.704 & 0.088 & 0.423 & 0.145 & 2.925 & 0.003 \\
\hline $\mathrm{MD} \rightarrow \mathrm{GPRD}$ & 0.102 & 0.501 & 0.774 & 0.439 & 0.508 & 0.139 & 3.654 & 0.000 \\
\hline $\mathrm{SV} \rightarrow \mathrm{GPRC}$ & 0.244 & 0.133 & 2.005 & 0.045 & 0.125 & 0.144 & 0.874 & 0.382 \\
\hline $\mathrm{SV} \rightarrow \mathrm{GPRD}$ & 0.323 & 0.097 & 2.695 & 0.007 & 0.090 & 0.136 & 0.665 & 0.506 \\
\hline
\end{tabular}

and tested empirically. Using data collected from a sample of 215 MENA region and GCC firms, the proposed relationships were tested.

The two research questions considered in this paper were addressed through the analysis of the collected data. The first question examined was that of determining the extent to which corporate environmental ethics, stakeholders' view of green product, market demand for green products, and big data influence green innovation, performance, and competitive advantage. The results confirmed that corporate environmental ethics, stakeholders' view and market demand for green product influence green innovation practice. In line with the results of Chang (2011) and Weng et al. (2015), corporate environmental ethics and stakeholders view were found to directly affect both green product and process innovation. Market demand for green product was found to have a positive direct influence on green process innovation and a marginal direct effect on green product innovation, partially supporting the findings of Lin et al. (2013) and Zailani et al. (2015).

Green product innovation was found to have a positive direct effect on environmental performance, but no significant effect on neither organizational performance nor competitive advantage. Green process innovation had a direct positive impact on both organizational and environmental performance but not on competitive advantage. Hence, green product innovation influences competitive advantage through environmental performance. That is, green product innovation leads to higher environmental performance which in turn enhances competitive advantage. Similarly, green process innovation impacts competitive advantage through both environmental and organizational performance. Thus, green process innovation leads to higher environmental and organizational performance which in turn enhances competitive advantage. These findings are consistent with those of Chen et al. (2006), Chang (2011), Lin et al. (2013), Sezen and Çankaya (2013) and Weng et al. (2015). Finally, the results of the direct effects indicated that big data and predictive analytics were found to influence organizational performance, thereby supporting the results of Gunasekaran et al. (2017). However, big data and predictive analytics was found to have a marginal direct influence on green product and process innovation.

Chang (2011) found that corporate environmental ethics impact competitive advantage through green process innovation, but not through green product innovation. Our results confirmed the indirect effects of the drivers of green innovation practices on performance and competitive advantage. Corporate environmental ethics were found to impact competitive advantage, organizational and environmental performance through green innovation practices. The influence of green product innovation on competitive advantage through environmental performance explains the discrepancies between our results and those of Chang (2011).

Table 15

Multi-group analysis for top management commitment (indirect effects).

\begin{tabular}{|c|c|c|c|c|c|c|c|c|}
\hline \multirow[t]{2}{*}{ TMC indirect } & \multicolumn{4}{|l|}{ High HRP } & \multicolumn{4}{|l|}{ Low HRP } \\
\hline & Path coeff. & STDEV & $t$-Values & p-Values & Path coeff. & STDEV & $t$-Values & p-Values \\
\hline $\mathrm{BDAS} \rightarrow \mathrm{CA}$ & 0.188 & 0.068 & 2.792 & 0.005 & 0.179 & 0.080 & 2.792 & 0.026 \\
\hline $\mathrm{BDAS} \rightarrow \mathrm{EP}$ & 0.068 & 0.046 & 1.485 & 0.138 & -0.002 & 0.032 & 1.485 & 0.956 \\
\hline $\mathrm{BDAS} \rightarrow$ OP & 0.039 & 0.033 & 1.187 & 0.235 & -0.009 & 0.019 & 1.187 & 0.638 \\
\hline $\mathrm{CEE} \rightarrow \mathrm{CA}$ & 0.051 & 0.035 & 1.439 & 0.150 & -0.001 & 0.025 & 1.439 & 0.956 \\
\hline $\mathrm{CEE} \rightarrow \mathrm{EP}$ & 0.374 & 0.065 & 5.781 & 0.000 & 0.429 & 0.069 & 5.781 & 0.000 \\
\hline $\mathrm{CEE} \rightarrow \mathrm{OP}$ & 0.126 & 0.061 & 2.076 & 0.038 & 0.024 & 0.073 & 2.076 & 0.744 \\
\hline $\mathrm{GPRC} \rightarrow \mathrm{CA}$ & 0.048 & 0.070 & 0.693 & 0.489 & 0.044 & 0.066 & 0.693 & 0.500 \\
\hline $\mathrm{GPRD} \rightarrow \mathrm{CA}$ & 0.034 & 0.036 & 0.962 & 0.336 & 0.000 & 0.022 & 0.962 & 0.997 \\
\hline $\mathrm{MD} \rightarrow \mathrm{CA}$ & 0.079 & 0.048 & 1.660 & 0.097 & 0.021 & 0.042 & 1.660 & 0.617 \\
\hline $\mathrm{MD} \rightarrow \mathrm{EP}$ & 0.046 & 0.037 & 1.251 & 0.211 & -0.009 & 0.027 & 1.251 & 0.732 \\
\hline $\mathrm{MD} \rightarrow \mathrm{OP}$ & 0.149 & 0.079 & 1.885 & 0.060 & 0.144 & 0.089 & 1.885 & 0.106 \\
\hline $\mathrm{SV} \rightarrow \mathrm{CA}$ & 0.049 & 0.077 & 0.638 & 0.524 & -0.135 & 0.095 & 0.638 & 0.157 \\
\hline $\mathrm{SV} \rightarrow \mathrm{EP}$ & 0.040 & 0.035 & 1.154 & 0.249 & -0.028 & 0.060 & 1.154 & 0.642 \\
\hline $\mathrm{SV} \rightarrow \mathrm{OP}$ & 0.082 & 0.060 & 1.378 & 0.168 & 0.046 & 0.087 & 1.378 & 0.599 \\
\hline
\end{tabular}


Consistent with the findings of Weng et al. (2015), stakeholders view was found to indirectly affect competitive advantage, organizational and environmental performance through green innovation practices. As for market demand for green product, it was found to indirectly influence competitive advantage, organizational and environmental performance through green innovation practices, thereby supporting the finding of Lin et al. (2013). Finally, in line with earlier results (Gunasekaran et al., 2017), big data and predictive analytics were found to indirectly influence competitive advantage through green innovation practices.

The second question examined was that of determining the extent to which management commitment and HR practices influence the relationships between green innovation practices, their key drivers, big data influence, performance, and competitive advantage. To investigate the role top management commitment and human resource (HR) practices play to overcome the technological challenges resulting from the adoption of green innovation and sustainable practices, multi-group analysis was employed. The results indicate that differences in the significance of several of the direct and indirect relationships examined in this study were exhibited among the groups of companies with low and high top management commitment, HR and training practices. Most differences revealed that the relationships are stronger for companies with higher such commitment and practices. For instance, the direct influence of corporate environmental ethics on green process innovation, green product innovation on environmental and organizational performance, and market demand for green products on green process innovation was stronger for companies with higher HR practices. Also, for these companies, the indirect influence of corporate environmental ethics on environmental and organizational performance as well as competitive advantage, green products innovation on competitive advantage, demand for green product on environmental and organizational performance, and stakeholders view on organizational performance was stronger. It is worth noting that the direct effect of environmental performance on competitive advantage was stronger for companies with lower HR practices indicating that through better environmental performance these companies may attain competitive advantage, most likely of the environmental type and not the economic type. On the other hand, companies with established HR practices attain a more balanced competitive advantage through a combination of better environmental and organizational performance. This supports the assertion that improvement in environmental performance is usually attained at the expense of economic growth (Wang and Song, 2014).

The multi-group analysis based on training practices suggests that higher level training is required for green product innovation to have a stronger influence on environmental performance, and stronger impact on green innovation practices when there is pressure from stakeholders. Moreover, training is required for demand for green product to have a significant positive impact on environmental performance through green innovation practices, and for stakeholders view to positively influence organizational performance and competitive advantage through these green innovation practices. However, the results indicate that companies with low training practices tend to react more to market demand for green product and may benefit in terms of environmental performance. On the other hand, companies with higher training practices may not react to the demand for green product unless balanced benefits are achieved. In addition, when under pressure from stakeholders, companies with low training practices may achieve some organizational performance. However, unlike companies with a higher level of training practices, competitive advantage may not be attained under such pressure. These results are in agreement with the conclusion of Weng et al. (2015) that green innovation practices should not only be a reaction to certain market demands or pressure from stakeholders, but an action to gain competitive advantage and achieve better performance. When under pressure from stakeholders, green innovation practices are achieved whenever top management is more committed to green practices. Moreover, when top management is more committed, Big Data Assimilation through adoption and routinization tend to be more incorporated and spread across the organization's processes in general and green processes in particular. In such companies, green product innovation and organizational performance are influenced by environmental ethics influence, while green product innovation is not influenced by the green product demand.

\subsection{Managerial implications}

The findings of this study suggest that engaging in environmental business practices, such as green innovation practices, may help companies gain competitive advantage and enhance their organizational and environmental performance. The adoption and implementation of such activities is driven by pressure from stakeholders, corporate environmental ethical practices and market demand for green product. The successful implementation of these practices require adequate adoption, routinization and assimilation of technology, such as big data and predictive analytics, as well as higher level of top management commitment, proper HR practices and employee training. These requirements not only help in overcoming the technological challenges of green innovation, but also in achieving a proper balance of higher organizational and environmental performance and gaining competitive advantage.

This study suggests several implications for managers and decision makers. First, the derivers of green innovations and the factors required for their successful implementation are identified. Recognizing and understanding these derivers and factors will help decision makers devise strategies and policies to successfully adopt green innovations and overcome the technological challenges. Moreover, this understanding can help managers successfully promote practices in their companies, and increase their commitment to green innovations, an essential factor for the successful implementation of the green innovation practices. Finally, this study identifies the effects of green innovations on organizational and environmental performance as well as competitive advantage. Hence, the study adds knowledge to the successful implementation and benefits of the of green innovations practices.

\subsection{Limitations and future scope of research}

By presenting and examining the model linking multiple constructs, this paper is one of the first works to deal with such a complex framework. Through the painstaking analysis of the model, we were able to determine the influence of corporate environmental ethics, stakeholders' view of green product, market demand for green products, and big data as well as management commitment and HR practices on green innovation, performance, and competitive advantage.

Although this study has certain limitations, they offer prospects and directions for future research. First, this study is quantitative in nature which could have benefited from a qualitative examination that reinforces the development of the proposed model. Moreover, cross examination of the results with experts and managers would have enriched the implications. The target population used in this study, MENA region and GCC firms, stands as another limitation. The results may have been influenced by aspects specific to the culture of the region under consideration. In addition, the conceptual model did not consider the full scope of the green supply chain management, green human resource management practices, and the social aspects of innovation and performance.

For future research, we suggest a combination of qualitative and quantitative study to further investigate the proposed model. Also, a cross cultural comparative analysis of the model can be conducted to examine differences in the relationships by selecting a sample of firms in counties with diverse cultures. Finally, the proposed model can be extended to incorporate green supply chain and green human resource 
management practices, as well as the social aspects of innovation and performance.

\section{References}

Amit, R., Schoemaker, P.J., 1993. Strategic assets and organizational rent. Strateg. Manag. J. 14, 33-46.

Ar, I.M., 2012. The impact of green product innovation on firm performance and competitive capability: the moderating role of managerial environmental concern. Procedia. Soc. Behav. Sci. 62, 854-864.

Astrachan, J.H., Kolenko, T.A., 1994. A neglected factor explaining family business success: human resource practices. Fam. Bus. Rev. 7 (3), 251-262.

Barney, J.B., 1986. Organizational culture: can it be a source of sustained competitive advantage? Acad. Manag. Rev. 11 (3), 656-665.

Barney, J., 1991. Firm resources and sustained competitive advantage. J. Manag. 17 (1), 99-120.

Barney, J., Wright, M., Ketchen, D.J., 2001. The resource-based view of the firm: ten years after 1991. J. Manag. 27, 625-641.

Boudreau, J.W., 2003. Sustainability and the talentship paradigm: strategic human resource management beyond the bottom line. In: CAHRS Working Paper Series, pp. 40.

Boudreau, J., Hopp, W., McClain, J.O., Thomas, L.J., 2003. On the interface between operations and human resources management. Manuf. Serv. Oper. Manag. 5 (3), 179-202.

Braganza, A., Brooks, L., Nepelski, D., Ali, M., Moro, R., 2017. Resource management in big data initiatives: processes and dynamic capabilities. J. Bus. Res. 70, 328-337.

Brandon-Jones, E., Squire, B., Autry, C.W., Petersen, K.J., 2014. A contingent resource based perspective of supply chain resilience and robustness. J. Supply Chain Manag. 50 (3), 55-73.

Cajaiba-Santana, G., 2014. Social innovation: moving the field forward. A conceptual framework. Technol. Forecast. Soc. Chang. 82, 42-51.

Chadwick, C., Super, J.F., Kwon, K., 2015. Resource orchestration in practice: CEO emphasis on SHRM, commitment-based HR systems, and firm performance. Strateg. Manag. J. 36 (3), 360-376.

Chan, H.K., He, H., Wang, W.Y., 2012. Green marketing and its impact on supply chain management in industrial markets. Ind. Mark. Manag. 41 (4), 557-562.

Chang, C.H., 2011. The influence of corporate environmental ethics on competitive advantage: the mediation role of green innovation. J. Bus. Ethics 104 (3), 361-370.

Chatterjee, D., Grewal, R., Sambamurthy, V., 2002. Shaping up for e-commerce: institutional enablers of the organizational assimilation of web technologies. MIS Q. 26 (2), 65-89.

Chen, C.M., Delmas, M.A., 2012. Measuring eco-inefficiency: a new frontier approach. Oper. Res. 60 (5), 1064-1079.

Chen, Y.S., Lai, S.B., Wen, C.T., 2006. The influence of green innovation performance on corporate advantage in Taiwan. J. Bus. Ethics 67 (4), 331-339.

Chin, W., 1998. Issues and opinion on structural equation modeling. MIS Q. 22, 7-16.

Chiou, T.Y., Chan, H.K., Lettice, F., Chung, S.H., 2011. The influence of greening the suppliers and green innovation on environmental performance and competitive ad vantage in Taiwan. Transport Res E-Log 47 (6), 822-836.

Chithambaranathan, P., Subramanian, N., Gunasekaran, A., Palaniappan, P.K., 2015. Service supply chain environmental performance evaluation using grey based hybrid MCDM approach. Int. J. Prod. Econ. 166, 163-176.

Chrisman, J.J., Chua, J.H., Zahra, S.A., 2003. Creating wealth in family firms through managing resources: comments and extensions. Enterp. Theory Pract. 27, 359-365.

Davenport, T.H., Barth, P., Bean, R., 2012. How big data is different. MIT Sloan Manag. Rev. 54 (1), 22-24.

Davison, A.C., Hinkley, D.V., 1997. Bootstrap Methods and Their Application. Cambridge University Press, Cambridge.

De Kok, J.M., Uhlaner, L.M., Thurik, A.R., 2006. Professional HRM practices in family owned-managed enterprises. J. Small Bus. Manag. 44 (3), 441-460.

DeSarbo, W.S., Wedel, M., Vriens, M., Ramaswamy, V., 1992. Latent class metric conjoint analysis. Mark. Lett. 3 (3), 273-288.

Dess, G.G., Limpkin, G.T., Taylor, M., 2005. Strategic Management, 2nd ed. McGraw-Hill Irwin, New York.

Dubey, R., Gunasekaran, A., Childe, S.J., Papadopoulos, T., Luo, Z., Wamba, S.F., Roubaud, D., 2017. Can big data and predictive analytics improve social and environmental sustainability? Technol. Forecast. Soc. Chang. http://dx.doi.org/10. 1016/j.techfore.2017.06.020. (in Press, Corrected Proof, Available online July 2017).

Fornell, C.G., Larcker, D.F., 1981. Evaluating structural equation models with unobservable variables and measurement error. J. Mark. Res. 18 (1), 39-50.

Fosso Wamba, S., Akter, S., Coltman, T., Ngai, W.T., E., 2015. Guest editorial: information technology-enabled supply chain management. Prod. Plan. Control 26 (12), 933-944.

Gholami, R., Sulaiman, A.B., Ramayah, T., Molla, A., 2013. Senior managers' perception on green information systems (IS) adoption and environmental performance: results from a field survey. Inf. Manag. 50 (7), 431-438.

Golicic, S.L., Smith, C.D., 2013. A meta-analysis of environmentally sustainable supply chain management practices and firm performance. J. Supply Chain Manag. 49 (2), 78-95.

Grant, R.M., 1991. The resource-based theory of competitive advantage: implications for strategy formulation. Calif. Manag. Rev. 33 (3), 114-135.

Grewal, R., Slotegraaf, R.J., 2007. Embeddedness of organizational capabilities. Decis. Sci. 38 (3), 451-488.

Größler, A., Griibner, A, 2006. An empirical model of the relationships between manufacturing capabilities. Int. J. Oper. Prod. Manag. 26 (5), 458-485.
Gunasekaran, A., Papadopoulos, T., Dubey, R., Wamba, S.F., Childe, S.J., Hazen, B., Akter, S., 2017. Big data and predictive analytics for supply chain and organizational performance. J. Bus. Res. 70, 308-317.

Hampton, S.E., Strasser, C.A., Tewksbury, J.J., Gram, W.K., Budden, A.E., Batcheller, A.L., Porter, J.H., 2013. Big data and the future of ecology. Front. Ecol. Environ. 11 (3), $156-162$.

Hashem, I.A.T., Yaqoob, I., Anuar, N.B., Mokhtar, S., Gani, A., Khan, S.U., 2015. The rise of "big data" on cloud computing: review and open research issues. Inf. Syst. 47, 98-115.

Hazen, B.T., Overstreet, R.E., Cegielski, C.G., 2012. Supply chain innovation diffusion: going beyond adoption. Int. J. Logist. Manag. 23 (1), 119-134.

Hitt, M.A., Ireland, R.D., Sirmon, D.G., Trahms, C.A., 2011. Strategic entrepreneurship: creating value for individuals, organizations, and society. Acad. Manag. Perspect. 25 (2), 57-75.

Huang, Y., Porter, A.L., Cunningham, S.W., Robinson, D.K., Liu, J., Zhu, D., 2017. A technology delivery system for characterizing the supply side of technology emergence: illustrated for big data \& analytics. Technol. Forecast. Soc. Chang. http://dx doi.org/10.1016/j.techfore.2017.06.020. (in Press, Corrected proof and Available online).

Hulland, J., 1999. Use of partial least squares (PLS) in strategic management research: a review of four recent studies. Strateg. Manag. J. 20 (2), 195-204 (Richard Ivey School of Business).

Jabbour, C.J.C., de Sousa Jabbour, A.B.L., 2016. Green human resource management and green supply chain management: linking two emerging agendas. J. Clean. Prod. 112, 1824-1833.

Jabbour, C.J.C., de Sousa Jabbour, A.B.L., Sarkis, J., Godinho Filho, M., 2017. Unlocking the circular economy through new business models based on large-scale data: an integrative framework and research agenda. Technol. Forecast. Soc. Chang. http:// dx.doi.org/10.1016/j.techfore.2017.09.010. (in Press, Corrected Proof and Available online).

Kamakura, W.A., Wedel, M., 2000. Factor analysis and missing data. J. Mark. Res. 37 (4), 490-498.

Kline, R., 2012. Beyond Significance Testing. American Psychological Association, Washington, DC.

Lado, A.A., Wilson, M.C., 1994. Human resource systems and sustained competitive advantage: a competency-based perspective. Acad. Manag. Rev. 19 (4), 699-727.

Li, F., Zhang, Z., Jin, C., 2016. Feature selection with partition differentiation entropy for large-scale data sets. Inf. Sci. 329, 690-700.

Liang, H., Saraf, N., Hu, Q., Xue, Y., 2007. Assimilation of enterprise systems: the effect of institutional pressures and the mediating role of top management. MIS Q. 31 (1), 59-87.

Lin, R.J., Tan, K.H., Geng, Y., 2013. Market demand, green product innovation, and firm performance: evidence from Vietnam motorcycle industry. J. Clean. Prod. 40, 101-107.

Lumpkin, G.T., Dess, G.G., 1996. Clarifying the entrepreneurial orientation construct and linking it to performance. Acad. Manag. Rev. 21 (1), 135-172.

Makadok, R., 1999. Interfirm differences in scale economies and the evolution of market shares. Strateg. Manag. J. 20, 935-952.

Marcus, A.A., Fremeth, A.R., 2009. Green management matters regardless. Acad. Manag. Perspect. 23 (3), 17-26.

Nunnally, J.C., Bernstein, I.H., 1994. Psychological Theory. McGraw-Hill, New York, NY.

Papadopoulos, T., Gunasekaran, A., Dubey, R., Fosso Wamba, S., 2017. Big data and analytics in operations and supply chain management: managerial aspects and practical challenges. Prod. Plan. Control 28 (11-12), 873-876.

Peng, Y.S., Lin, S.S., 2008. Local responsiveness pressure, subsidiary resources, green management adoption and subsidiary's performance: evidence from Taiwanese manufactures. J. Bus. Ethics 79, 199-212.

Rajesh, R., 2017. Technological capabilities and supply chain resilience of firms: a relational analysis using Total Interpretive Structural Modeling (TISM). Technol. Forecast. Soc. Chang. 118, 161-169.

Ravichandran, T., Lertwongsatien, C., 2005. Effect of information systems resources and capabilities on firm performance: a resource-based perspective. J. Manag. Inf. Syst. 21 (4), 237-276.

Reinhardt, F.L., 1998. Environmental product differentiation: implications for corporate strategy. Calif. Manag. Rev. 40 (4), 43 e73.

Roßmann, B., Canzaniello, A., von der Gracht, H., Hartmann, E., 2017. The future and social impact of big data analytics in supply chain management: results from a Delphi study. Technol. Forecast. Soc. Chang. http://dx.doi.org/10.1016/j.techfore.2017.10. 005. (in Press, Corrected Proof and Available online).

Routroy, S., 2009. Antecedents and drivers for green supply chain management implementation in manufacturing environment. ICFA J. Supply Chain Manag. 6, 20-35.

Roxas, B., Lindsay, V., 2012. Social desirability bias in survey research on sustainable development in small firms: an exploratory analysis of survey mode effect. Bus. Strateg. Environ. 21 (4), 223-235.

Rungtusanatham, M., Salvador, F., Forza, C., Choi, T.Y., 2003. Supply-chain linkages and operational performance: a resource-based-view perspective. Int. J. Oper. Prod. Manag. 23 (9), 1084-1099.

Saga, V.L., Zmud, R.W., 1994. The nature and determinants of information technology acceptance, routinization, and infusion. In: L. (Ed.), Diffusion, Transfer, and Implementation of Information Technology. Elsevier Science, Amsterdam, pp. 67-86.

Sezen, B., Çankaya, S.Y., 2013. Effects of green manufacturing and eco-innovation on sustainability performance. Procedia. Soc. Behav. Sci. 99, 154-163.

Sirmon, D.G., Hitt, M.A., 2003. Managing resources: linking unique resources, management, and wealth creation in family firms. Enterp. Theory Pract. 27 (4), 339-358.

Sirmon, D.G., Hitt, M.A., Ireland, D., 2007. Managing firm resources in dynamic environments to create value: looking inside the black box. Acad. Manag. Rev. 32 (1), 
273-292.

Sirmon, D.G., Gove, S., Hitt, M.A., 2008. Resource management in dyadic competitive rivalry: the effects of resource bundling and deployment. Acad. Manag. J. 51 (5), 919-935.

Sirmon, D.G., Hitt, M.A., Ireland, R.D., Gilbert, B.A., 2011. Resource orchestration to create competitive advantage: breadth, depth and life cycle effects. J. Manag. 37, $1390-1412$.

Sivarajah, U., Kamal, M.M., Irani, Z., Weerakkody, V., 2017. Critical analysis of big data challenges and analytical methods. J. Bus. Res. 70, 263-286.

Song, M.L., Fisher, R., Wang, J.L., Cui, L.B., 2016. Environmental performance evaluation with big data: theories and methods. Ann. Oper. Res. 1-14.

Tien, J.M., 2013. Big data: unleashing information. J. Syst. Sci. Syst. Eng. 22 (2), 127-151.

Ulrich, D., Lake, D., 1990. Organizational capability: Competing from the inside out. John Wiley \& Sons, New York.

Wang, S.H., Song, M.L., 2014. Review of hidden carbon emissions, trade, and labor income share in China, 2001-2011. Energ Policy 74, 395-405.

Wei, Y., Morgan, N.A., 2004. Supportiveness of organizational climate, market orientation, and new product performance in Chinese firms. J. Prod. Innov. Manag. 21, 375-388.

Weng, H.H.R., Chen, J.S., Chen, P.C., 2015. Effects of green innovation on environmental and corporate performance: a stakeholder perspective. Sustainability 7 (5), 4997-5026.

Wetzels, M., Odekerken-Schröder, G., Van Oppen, C., 2009. Using PLS path modeling for assessing hierarchical construct models: guidelines and empirical illustration. MIS Q. 177-195.

Wu, F., Yeniyurt, S., Kim, D., Cavusgil, S.T., 2006. The impact of information technology on supply chain capabilities and firm performance: a resource-based view. Ind. Mark Manag. 35 (4), 493-504.

Wu, X., Zhu, X., Wu, G.Q., Ding, W., 2014. Data mining with big data. IEEE Trans. Knowl. Data Eng. 26 (1), 97-107.

Yen, Y.X., Yen, S.Y., 2012. Top-management's role in adopting green purchasing standards in high-tech industrial firms. J. Bus. Res. 65 (7), 951-959.

Zailani, S., Govindan, K., Iranmanesh, M., Shaharudin, M.R., Chong, Y.S., 2015. Green innovation adoption in automotive supply chain: the Malaysian case. J. Clean. Prod. 108, 1115-1122.

Zhou, K.Z., Brown, J.R., Dev, C.S., 2009. Market orientation, competitive advantage, and performance: a demand-based perspective. J. Bus. Res. 62, 1063-1070.

Zhu, Q., Sarkis, J., Lai, K.H., 2013. Institutional-based antecedents and performance outcomes of internal and external green supply chain management practices. J. Purch. Supply Manag. 19 (2), 106-117.

Zmud, R.W., Apple, L.E., 1992. Measuring technology incorporation/infusion. J. Prod. Innov. Manag. 9 (2), 148-155.

Abdul-Nasser El-Kassar, Ph.D. is Associate Professor of Quantitative Methods, Adnan Kassar School of Business, Lebanese American University, Beirut, Lebanon. His research areas include Cryptography, Abstract algebra, Number theory, and Big data analytics.

Sanjay Kumar Singh, Ph.D. is Associate Professor of Management, College of Business, Abu Dhabi University, Abu Dhabi, UAE. His research areas include Big data analytics, Knowledge management, Organizational learning, Leadership \& Culture and International HRM. 